\title{
Tarihi Rombaki Yığma Yapısının Performans Değerlendirmesi
}

\author{
Memduh KARALAR*, Murat ÇAVUŞLI \\ Zonguldak Bülent Ecevit Üniversitesi, İnşaat Mühendisliği Bölümü, Zonguldak \\ (ORCID: 0000-0002-4595-8971) (ORCID: 0000-0002-2285-8513)
}

\begin{abstract}
Özet
Tarihi yığma yapıların, günümüz yaşam standartları göz önünde bulundurulduğunda yeniden kullanılacak hale getirilmesi, ülkemizin tarihi ve turizmi açısından hayati önem taşımaktadır. Bu çalışmada, Zonguldak ilinde 1941 yılında inşa edilmiş tarihi bir yığma yapının performansı değerlendirilmiş̧tir. 1941 yılında sosyal tesis olarak faaliyete geçen bu yığma yapı, bir süre Aile ve Sosyal Politikalar Bakanlığı'nca huzurevi olarak kullanılmıştır. Bina, Türkiye Taş Kömürü (TTK) Üzülmez Müessese Müdürlüğünce pansiyon olarak işletilmeye devam edilmektedir. Ancak bu binanın tarihi eser olması sebebiyle uzun yıllar boyunca ülke turizmine hizmet etmesi gerekmektedir ve bu yığma binanın güçlendirilmesi turizm açısından hayati önem arz etmektedir. Güçlendirme işlemleri için ilk olarak tarihi binanın rölevesi çıkarılmıştır. Her bir taşıyıcı eleman ayrıntılı olarak belirlenmiştir. Daha sonra, yığma yapı STATICAD yığma programı yardımıyla 3 boyutlu olarak modellenmiştir. Modelleme yapılırken, ana projeye sadık kalınmıştır. Analiz sonucunda binanın çok uzun süre ayakta kalamayacağı anlaşılmıştır ve binanın belirli bölgelerine 2018 Türk Deprem Yönetmeliği göz önünde bulundurularak deprem güçlendirmeleri yapılmıştır. Güçlendirme sonrasında devrilmeye karşı koyan devrilme momenti değerleri ve depremden dolayı katlara gelen kesme kuvveti değerleri yönetmeliğe uygun sınırlar içerisine getirilmiştir. $\mathrm{Bu}$ çalışma ile yığma binanın performansının hemen kullanım olması sağlanmıştır ve ülkemizin turizmine katkı sağlamak için önemli bir adım atılmıştır.
\end{abstract}

Anahtar kelimeler: Tarihi eser binalar, Yığma yapılar, Performans değerlendirmesi.

\section{Performance Evaluation of Historical Rombaki Masonry Building}

\begin{abstract}
The fact that the historical masonry structures are to be re-used in view of today's living standards is of vital importance for the history and tourism of our country. In this study, the performance of a historical masonry building built in 1941 in Zonguldak province was evaluated in detail. This masonry building, which became operational as a social facility in 1941, was used as a nursing home for a while by the Ministry of Family and Social Policies. The building continues to be operated as a hostel by the Directorate of Turkish Hardcoal Authority (TTK). However, due to the fact that this building is a historical work, it has to serve for the tourism of the country for many years, and the strengthening of this masonry building is of vital importance for tourism. Firstly, relievo of the historic building was obtained for strengthening. Each structural element is identified in detail. 3D model of masonry building was performed using STATICAD masonry program. During the modeling process, the main project was taken into account. As a result of the analysis, it was understood that the building could not survive for a very long time and earthquake strengths were made to main sections of the building considering the 2018 Turkish Earthquake Code (TEC). After the strengthening of this masonry building, the values of the tilting moments against the tipping and the earthquake shear force values for floors were brought within the limits appropriate to TEC. With this study, the performance of masonry building was ensured as immediate occupancy and an important step was taken to contribute to the tourism of our country.
\end{abstract}

Keywords: Historical buildings, Masonry buildings, Performance evaluation.

\footnotetext{
*Sorumlu yazar: memduhkaralar@beun.edu.tr Geliş Tarihi: 03.04.2019, Kabul Tarihi: 11.07.2019
} 


\section{Giriş}

Ülkemiz, çok eski bir tarihi geçmişe sahiptir ve bu tarihi geçmiş farklı yüzyıllara ait birçok yapıyı miras olarak bizlere bırakmıştır. Bu tarihi miras içerisinde yığma sistemle yapılmış yapılardan, farklı medeniyetlerin yaptığı betonarme yapılara kadar çok sayıda farklı koruma problemleri içeren yapı tipleri olduğu görülmektedir. Güçlendirme ve koruma prensipleri, tarihi yapıların hepsi için aynı duyarlılık ve hassasiyet içinde uygulanması gerekmektedir ve bu güçlendirme çalışmaları standartlara uygun olarak yapılmalıdır. Tarihi eser niteliğindeki yapıların güçlendirilmesi ve korunmasındaki asıl amaç, bu yapıların deprem ve yapısal güvenliğini koruyarak uzun süre ayakta kalabilmelerinin sağlanmasıdır. Ancak, bu hayati işlemler uygulanırken tarihi yapının tarihi dokusunun bozulmaması esas olmalıdır. Son zamanlarda ülkemizdeki tarihi yapılar, deprem gibi kuvvetli yer hareketleri, sel ve son zamanlarda meydana gelen hızlı kentleşmenin olumsuz tehdidi ile karşı karşıyadır. Tarihi eserlerin korunmasında ülkemiz, kendi himayesi altındaki büyük ölçekli kamusal yapıları özenle korumaya çalışırken, özellikle çoğu özel mülkiyette olan küçük ölçekli yapıları yasal altyapıdaki eksiklikler nedeniyle yeterince koruyamamaktadır. Bu nedenle, son zamanlarda birçok tarihi yığma yapı "yıkılmaya eğilimli" anlamına gelen "mail-i inhidam" durumunda olması nedeniyle yıkılmıştır. Hâlbuki bu yığma binalar, deprem güçlendirmesi yapılıp uzun süre hem yöre halkına hem de ülke turizmine hizmet verebilirlerdi. Tarihi bir yığma yapının dayanımı, yapısal sisteme, yapının geometrisine ve bina yapılırken kullanılan malzemenin mekanik özelliğine bağlıdır. Bu sebeple, birbirine benzeyen tarihi yığma yapılarda sabit yükler altında farklı yapısal deformasyon ve yenilmeler meydana gelebilmektedir. Tarihi yığma yapılarda meydana gelen yenilmelerin sebepleri yapının kendi ağırlığıyla oluşan yükler, yer titreşimlerinden oluşan yükler ve diğer doğal afetlerin neden olduğu yüklerdir. Fakat tarihi yığma bir yapının kendi ağırlığından dolayı yıkılması veya zarar görmesi çok nadir görülen bir durumdur. Tarihi yapıların zarar görmesi veya yıkılmasının asıl sebebi, doğal dış yükler, insan kaynaklı yapay yüklerdir veya diğer çevresel etkilere bağlı yapısal sorunlardır [1]. Literatürde, tarihi yapıların güçlendirilmesi ve yeniden kullanıma kazandırılması ile ilgili çalışmalar şu şekilde özetlenmiştir; Tarihi eserlerde, yığma duvarların, kubbelerin, tonozların ve temellerin enjeksiyon reçineleri ve ankraj sistemleriyle güçlendirilmesi ile ilgili bir çalışma yapılmıştır. Çalışmada, reçinelerin basınç ve kesme-eğilmebükülme dayanımlarının çok yüksek olduğu belirtilmiştir. Söz konusu reçinelerin reaksiyona girme süresi 30-180 saniye arasında değiştiği görülmüsştür. Carbopur WF reçinesinin susuz ortamda hacimsel olarak şişmediği ve basınç dayanımları birkaç dakika içinde $800 \mathrm{~kg} / \mathrm{cm}^{2}$ civarına ulaştığı belirtilmiştir. Carbopur S reçinesinin ise susuz ortamda da \% 100-200 oranında şiştiği ve basınç dayanımı yine birkaç dakika içinde $100-300 \mathrm{~kg} / \mathrm{cm}^{2}$ civarında gerçekleştiği belirtilmiştir. Çift komponentli reçinelerin serbest ortamlarda (havayla direk temas gibi) şişme ve köpüklenme oranı 2-6 civarında olduğu gösterilmiştir. Ancak bunların beton ve zemin gibi ortamlardaki şişme oranları 1.0-2.5 arasında olduğu belirtilmiştir. $\mathrm{Bu}$ reçinelerin çekme, burulma ve basınç mukavemetleri çok yüksek olduğu ispatlanmıştır [2]. Ayrıca Adana Ulucami minaresinde güçlendirme çalışması 2007 yılında yapılmıştır. Adana Ulucami Kulesindeki birbirinden ayrışmış ve kopmuş taşlar, çatlaklar çok iyi yapışan reçinelerle doldurulmuştur. $\mathrm{Bu}$ doldurma işlemi ile taşların genleşme nedeniyle daha fazla çatlaması, çatlaklara su sizarak içindeki malzemeyi yıkaması ve çatlakları genişletmesi önlenmiştir. Ayrıca çatlaklardaki suyun donması halinde çatlakları daha çok açması, taşın orijinal basınç mukavemetine yakın bir mukavemette takviye edilerek mukavemeti azaltacak kesit daralması ve ana çatlak yakınındaki kılcal çatlakları baştan kapatarak bu çatlakların büyümesi önlenmiştir [3]. Daha sonra Ahi Çelebi Camisinin onarımı ve güçlendirilmesi hakkında bir çalışma yapılmıştır. Bu çalışmada düşey yükler, mesnet çökmeleri, deprem gibi etkiler nedeniyle hasar görmüş yı̆̆ma kargir kubbelerin onarım ve güçlendirme yöntemleri, mesnet bölgesinde oluşturulan çekme çemberinin güçlendirmedeki etkinliği Ahi Çelebi Camisi uygulama örneği ile verilmiştir. Yap1, düşey ve deprem yükleri etkisi altında SAP2000 yazılımı kullanılarak modellenmiştir. Dıştan çekme çemberi uygulaması, kubbede oluşan çekme gerilmelerinin önemli miktarda azalmasına ve kubbe yüzeyinde daha uygun bir gerilme dağılişına götürmüştür [4]. Ek olarak teknik ekiplerce yıkılıp yeniden inşa edilmesi önerilmiş olan bir yapının güçlendirmesi yapılmıştır. Yapı, 1999 Doğu Marmara Depremi'nde yırtılan Arifiye fay zonuna sadece yaklaşık 7,5 km uzaklıkta bulunmaktadır. Bu çalışma sonucunda yapının güçlendirme ve onarım projesi yapılmış ve bina depremden sekiz ay sonra hizmete açılmıştır. Yapının (taban kesme kuvveti - tepe yerdeğiştirme) davranış eğrisi "hemen kullanım” düzeyinde kalmışıtır [5]. Ayrıca Urla Eski Tekel Binasının (Arditi Köşkü) yangın öncesi durumu ve yapının güçlendirilmesi ile ilgili bir çalışma yapılmıştır. Yangın öncesinde yapının dış 
duvarları ayakta olmakla beraber yer yer yapıda göçme ve çürümeler olduğu tespit edilmiştir. Yapılan incelemeler, yapının özellikle sismik etkiler altında yetersizlikler içerdiğini ve yapısal sistemin karmaşıklığı sebebiyle basit müdahalelerin işe yaramayacağını göstermiştir. Bu sebeple belirli seviyede sismik güvenlik sağlayacak ve yapının mimari miras değerlerine mümkün olan en az etkiyi yapacak, taşıyıcı sistem müdahalelerinin gerçekleştirilmesi gerektiğine karar verilmiştir. Sismik iyileştirmeyi etkin bir seviyeye çıkarabilmek için hem eleman bazında hem de sistem bazında müdahaleler öngörülmüş ve detaylandırılmıştır [6]. Sert ve Partal yaptıkları çalışmada tarihi köprülerin restorasyonları kapsamında yürütülen yapısal analiz çalışmaları ve sonuçlarını detaylı olarak sunmuşlardır. Çalışmada, söz konusu araştırmaların yapılmadığı/yetersiz olduğu durumlarda restorasyon sonrası yapıda tekrar hasarlar meydana gelebileceği ispatlanmıştır. Yapı ve zemin ile ilgili tespitler tarihi köprülerin taşıyıcı sistemlerinin yanı sıra temellerinde ve üzerinde bulundukları dere yataklarında yapılacak iyileştirme çalışmalarına ilişkin belirlenen tekniklerin de desteklenmesi açısından önem arz etmekte olduğu belirtilmiştir [7]. Daha sonra, ölçekli yığma taş kemer köprü modelinin dinamik davranışını deneysel ve analitik olarak incelenmiştir. Çalışmada, uygulamalarda sıklıkla karşılaş1lan bir taş kemer köprünün laboratuvar ortamında oluşturulmuş 1/10 ölçekli modelinin dinamik davranışı deneysel olarak incelenmiştir. Çevresel titreşim testi kullanılarak gerçekleştirilen modelin ilk altı frekansı, mod şekli ve modal sönüm oranı belirlenmiştir. Ölçüm sırasında modele zarar vermemek amacıyla ilave titreştirici kullanılmadan çevreden gelen titreşimler altında köprü davranışı tek eksenli sismik ivme ölçerler ile belirlenmiştir. SAP2000 programında üç boyutlu katı elemanlar kullanılarak oluşturulan model üzerinde modal analiz gerçekleştirilerek dinamik karakteristikler analitik olarak belirlenmiştir. Çalışmanın sonunda, deneysel olarak elde edilen dinamik karakteristikler ile analitik sonuçlar karşılaştırılmış ve farklılıklar ortaya konulmuştur [8]. Ayrıca tarihi Malabadi Köprüsü'nde yürütülen restorasyon-konservasyon çalışmaları hakkında bir çalışma yapılmıştır. Diyarbakır ili, Batman Suyu üzerinde, Artuklular Döneminde inşa edilmiş, 40.86m açıklığındaki sivri ana kemeri ile dünyanın günümüze ulaşan en büyük kemer açıklığına sahip taş kemer köprüsü olan Tarihi Malabadi Köprüsü’nde, 2009-2013 yılları arasında Karayollar1 Genel Müdürlüğü tarafından gerçekleştirilen restorasyon-konservasyon çalışmaları detaylı olarak anlatılmıştır. Güçlendirmenin önemi bu çalışma ile belirtilmiştir [9]. Tunceli ilinin Çemişgezek ilçesindeki Tağar çayı üzerinde bulunan tarihi Tağar köprüsünün doğrusal ve doğrusal olmayan sismik analizleri yapılmıştır. Bu amaçla köprü üç boyutlu sonlu elemanlarla modellenmiştir. Sismik etki olarak Erzincan depreminin ivme kayıtları dikkate alınmıştır. Analizlerde ANSYS sonlu eleman programı kullanılmıştır. Analizden elde edilen sonuçlar karşılaştırılarak köprünün sismik davranışı incelenmiştir [10]. Tarihi yapılarda taşıyıcı sistem özellikleri, hasarlar, onarım ve güçlendirme teknikleri hakkında bir çalışma yapılmıştır. Çalışmada, geçmişten günümüze koruma kavramının nasıl algılandığ ve ne gibi adımların atıldığ 1 ve tarihi yapı türleri, tarihi yapılarda kullanılan malzeme ve özellikleri hakkında bilgiler verilmiştir. Ayrıca tarihi yapıyı oluşturan taşıyıcı sistem özellikleri, bu yapılarda meydana gelen hasarlar ve günümüzde uygulanan hasar tespit yöntemleri, yığma kargir binaların deprem yönetmeliğinde belirtilen koşullar çerçevesinde deprem güvenliğinin incelenmesi ve tarihi yapılarda uygulanan onarım ve güçlendirme teknikleri hakkında detaylı bilgiler sunulmuştur [11]. Literatürdeki çalışmalardan da görüldüğü gibi, geçmişte tarihi yapılarla ilgili birçok çalışma bulunmaktadır. Fakat turizm açısından önem arz eden ve halkın sıkça kullandığı bir mekân olan tarihi yığma konakların 2018 Türk deprem yönetmeliği göz önünde bulundurularak güçlendirilmesi ve deprem performansı ile ilgili bir çalışma bulunmamaktadır. Bu çalışmanın amacı, ülke turizmi için önemli olan tarihi konakların uzun süre ayakta kalabilmesi için deprem güçlendirmelerinin yapılması ve deprem performanslarının değerlendirilmesidir. $\mathrm{Bu}$ amaçla, analizler ve değerlendirmeler için 1941 yılında inşa edilen tarihi bir yığma konak seçilmiştir. Bu konak, Zonguldak ve ülkemiz turizmi için çok önemlidir ve bu yapının ömrünün uzatılması hayati önem arz etmektedir. Bu sebeple, bu çalışma literatüre ve ülke turizmine önemli katkılar vermektedir. Domaneschi ve diğ 2019 yılında yığma yapılar hakkında numerik bir çalışma yapmışlardır. $\mathrm{Bu}$ çalışmada yığma yapıların yıkıldıktan sonraki enkaz hacminin tahmini ve yığma yapıların performansı hakkında bir metot önerilmiştir [12]. Zhang ve Beyer duvarlar arası etkileşimin yığma yapıların kesme dayanımına olan katkılarını araştırmışlardır. Duvarlar arası kenetlenmenin yığma yapıların performansı üzerinde çok büyük etkileri olduğu sonucuna varılmıştır [13]. Boschi ve diğ. Yığma yapıların sismik kırılganlığını incelemişlerdir. Yapı elemanları arasındaki etkileşim ve yapının alt kısmındaki tonozların etkisi de analizler içerisinde dikkate alınmıştır. Analizler, zayıf duvarların bağlantılarının ve duvar tipinin kalitesizliğinin yığma yapıların performansını ciddi derecede etkilediğini göstermiştir [14]. 
Masoomi ve Lindt kasırga rüzgâr yüklerine maruz kalan yığma bir okul binasının performansı incelemişlerdir. Kasırga kırılganlık değerlendirme metodunu kullanmışlardır ve bu metodun yığma yapılarda zarar tahmininde dikkate alınması önerilmiştir [15]. Araújo ve diğ. duvar ile ahşap arasındaki bağlantının yığma yapıların performansına olan etkilerini ve yığma yapıların güçlendirilmesini incelemişlerdir. Yapının belirli bölgelerine etki ettirilen ankrajların yığma yapıların performansını ciddi anlamda etkilediği belirtilmiştir [16]. Işık ve diğ. sismik açıdan oldukça hareketli olan Van Gölü Havzasında yer alan Bitlis ili, Merkez ilçesinde bulunan tarihi bir yı̆̆ma yapı için deprem güvenlik hesaplamaları gerçekleştirmiştir. Çalışmada yığma yapılar için dikkate alınabilecek üç inceleme seviyesinden birinci çözümleme seviyesi kullanılmıştır. Yapıda oluşan maksimum kayma gerilmesi ve malzeme için verilen sınır değerler karşılaştırdığında yapı her iki doğrultuda kayma gerilmeleri açısından deprem güvenliğini sağlamaktadır [17]. Karaşin ve diğ. Diyarbakır Sur içinde yer alan tarihi bir yığma yapı iki farklı hızlı değerlendirilme yöntemi ile değerlendirmiştir. Çalışmada, Çevre ve Şehircilik Bakanlığının 2013 yılında yayınladığı yönetmelikte yer alan yığma yapılar için birinci aşama değerlendirme ve Kanada Sismik tarama yöntemi kullanılarak seçilen yığma bina değerlendirilmiştir. Kullanılan yöntemlerden biri olan Kanada Sismik Tarama yöntemine göre incelenen bina için SI/NSI = $74.62 / 75.92=0.98$ değeri elde edilmiştir. Bu değer sismik güvenlik değerinin altındadır. Yapı için hesaplanan SPI değeri 75.92 çıkmış ve bu değerde binanın oldukça tehlikeli olduğu sonucunu ortaya çıkarmıştır [18]. Işık ve Antep, 1584 yılında inşa edilen Kadı Mahmut Cami'sine ait yığma tarzda inşa edilen cami minaresini dikkate almışlardır. Minare kesme Ahlat taşından yapılmışırı. $2.75 \mathrm{mx} 2.75 \mathrm{~m}$ boyutlarında kare plan üzerine kurulan minarenin gövdesi $2 \mathrm{~m}$ çapında silindirik bir yapıya sahiptir. Minarenin toplam yüksekliği $25.10 \mathrm{~m}$ 'dir. Yerinde yapılan ölçümler sonucu elde edilen değerler yardımı ile minarenin üç boyutlu modeli yazılım programında oluşturulmuştur. Oluşturulan model sonlu elemanlar yöntemi ile analiz edilmiştir. Farklı yükleme durumlarına göre yapının deprem davranışı belirlenmeye çalışılmıştır. Kadı Mahmut Cami'sine ait minare için kullanılan farklı yük kombinasyonları dikkate alındığında en büyük basınç gerilme değerinin $2.723 \mathrm{MPa}$; en büyük kayma gerilmesi 1.339MPa ve en büyük çekme gerilmesinin 1.232MPa olduğu belirlenmiştir. Minarede oluşan en büyük gerilmeler minaredeki geçiş bölgeleri olarak belirlenmiştir. Elde edilen bu değerlerin yapi tarafindan karşılanabileceği sonucu ortaya çıkmaktadır. Minare için birinci mod hareketinde kaideye göre gövde ve petek elemanlarının etkisi daha büyüktür [19]. Işık ve diğ. Hüseyin Timur Türbesini numerik olarak incelediler. Hüseyin Timur Türbesi, Türk mimarisinin önemli anıtlarından biridir. Ayrıca Unesco kültürel mirasının içinde yer almaktadır. Yapı içerisinde maksimum gerilmeler zemin seviyesinde taban duvarlarında elde edilmiştir ve maksimum $6.1 \mathrm{MPa}$ 'lık bir gerilme değeri gözlemlenmiş̧tir. Ayrıca, kubbenin tepesinde yaklaşık 13 mm'lik maksimum yer değiştirmenin olacağını kanısına varılmıştır [20].

\section{Yöntem}

Bu çalışmada, ilk olarak yığma konağın rölevesi çıkarılmıştır. Çünkü bu yapı, tarihi eser niteliğinde olan bir bina olduğundan dolayı o döneme ait hiçbir proje veya teknik bilgiye ulaşılamamıştır. Her bir taşıyıcı eleman uzunlukları detaylı olarak belirlenmiştir ve AUTOCAD programına girilmiştir. Döşemelerin ahşaptan yapılmış olması döşeme kalınlığının belirlenmesine engel olsa bile her bir döşemeden kalınlık ve uzunluk bilgileri ayrıntılı olarak elde edilmiştir. Daha sonra rölevesi çıkarılan binanın 3 boyutlu modeli STATICAD yığma programı yardımıyla oluşturulmuştur. Tüm taşıyıcı elemanlar programa özenle girilmiştir ve döşemeler projeye uygun olarak oluşturulmuştur. Bu yığma bina, ülke turizmi açısından çok önemli olması sebebiyle binadan numune alınarak malzeme parametrelerinin belirlenmesi tarihi dokuya zarar vereceği sebebiyetiyle literatür araştırması yapılarak malzeme parametreleri belirlenmiştir. Tüm taşıyıcıların malzeme parametreleri programa özenle tanımlanmıştır. Analizler ilk olarak yapının şu anki durumu göz önünde bulundurularak yapılmıştır. Analiz sonuçlarına göre, yapının daha fazla ayakta kalmakta zorlandığı ve deprem güçlendirmesinin yapılmasının şart olduğu görülmüştür. Sonuçlar detaylı incelenerek güçlendirme yapılması gereken taşıyıcılar belirlenmiştir ve bu taşıyıcı duvarlara güçlendirme mantolaması yapılmıştır. Bu taşıyıcılar, mantolama işlemi için ilk olarak dış duvarlardan seçilmiştir. Mantolama yapılırken tarihi eserin çok fazla zarar görmemesine özen gösterilmiştir. Güçlendirme yapılan yapı tekrar analiz yapıldığında çoğu duvarın mantolama sonucunda ayakta uzun yıllar kalabileceği ancak bazı iç duvarların zamanla yıkılabileceği görülmüştür. Tekrar 
mantolama işlemleri yapılarak zorlanan taşıyıcılar desteklenerek yapının uzun yıllar ülke turizmine ve ülke ekonomisine katkı vermesi sağlanmış oldu.

\section{Rombaki Tarihi Yığma Bina Hakkında Genel Bilgiler}

Cumhuriyetin ilanından sonra Zonguldak ili ekonomik olarak büyük yatırımların yapıldığı bir il olmuştur. İş adamlarının ve ülkemizin yaptığı yatırımlar sonucunda Zonguldak Türkiye'nin en fazla nüfusu olan illerden biri haline gelmiştir. Rombaki yığma konağı, 1941 yılında Cumhuriyetin ilanından sonra Zonguldak Üzülmez 'de inşa edilmiş tarihi bir yapı olup çok uzun süre ülkemizin turizmine hizmet etmiştir. Bu çalışmaya konu olan Rombaki yığma konağı Cumhuriyetin ilanından sonra Zonguldak'a bırakılmış en büyük tarihi miraslardan biridir (Şekil 1). 1950'li yıllarda bu konakta o dönemin zengin iş adamları yaşamaktaydı. Konağın etrafinda olabildiğince yeşil yaşam alanları mevcuttur. Bu yeşil alanlar, o dönemlerde yeşile ve doğaya ne kadar önem verildiğinin göstergesidir. Bina, Zonguldak merkeze 2 km uzaklıkta olup şehrin turizmi açısından hayati öneme sahiptir. 1970'lı yıllarda binanın dış kısmı tadilatla onarılıp şu anki haline dönüştürülmüştür. Ancak, 1941 yılından beri yapının taşıyıcılarına herhangi müdahale yapılmamıştır. Bu sebeple yapının yeterince yorulduğu ve daha uzun süre ayakta kalabilmesi için tadilat gereksinimine ihtiyaç olduğu düşünülmüştür. Bu konak, yığma bir yapı olup dış kısmı kalın taş duvarlardan inşa edilmiştir. Yapıda, yaklaşık 1 metreye yakın kalınlıkta dış duvarlar mevcut olup döşemelerinin tamamı ahşaptan yapılmıştır. Yapıda kullanılan taş duvarların elastisite modülleri $800 \mathrm{MPa}$ ve Poisson oranı 0.22'dir. Ayrıca duvarların birim hacim ağırlıkları $1500 \mathrm{~kg} / \mathrm{m}^{3}$ 'tür ve duvar çatlama emniyet gerilmesi $0.25 \mathrm{MPa}$ 'ır. En alt katı bodrum kattır ve o dönemde bu kat çamaşırhane olarak kullanılmıştır. Zemin kat ile bodrum kat planları birbirinin aynısıdır (Şekil 2a). Bodrum katın üzerinde toplam 3 kat bulunmaktadır. Her katın geometrik yapıları birbirinden farklıdır. Ayrıca, 1. ve 2. katın planları da birbiri ile aynıdır (Şekil 2b). En üst kata küçük bir çatı katı yapılmıştır. Fakat çatı katı her kattan küçüktür ve çatı tamamen ahşaptan yapılmıştır. Şekil 3, 4 ve 5'de sırasıyla yapının düşey kesitleri detaylı olarak sunulmuştur.
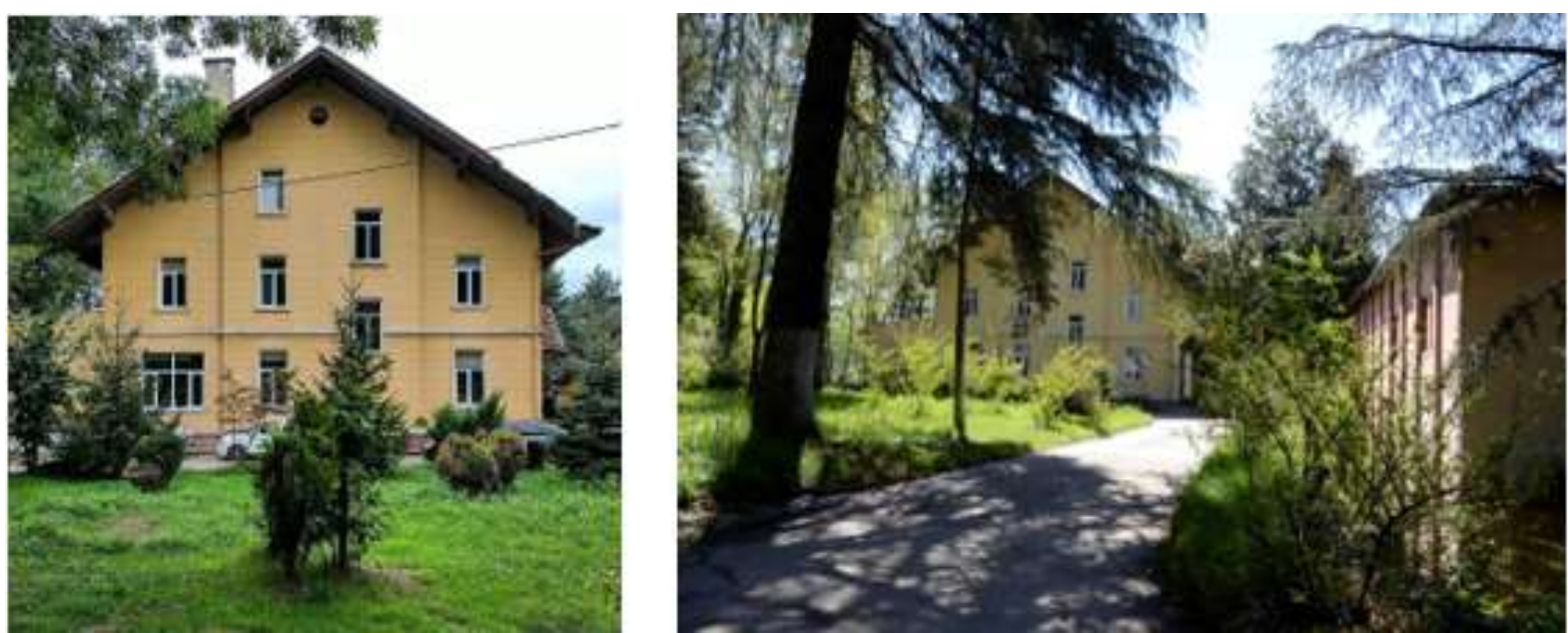

Şekil 1. Tarihi yığma yapının genel görüntüleri 

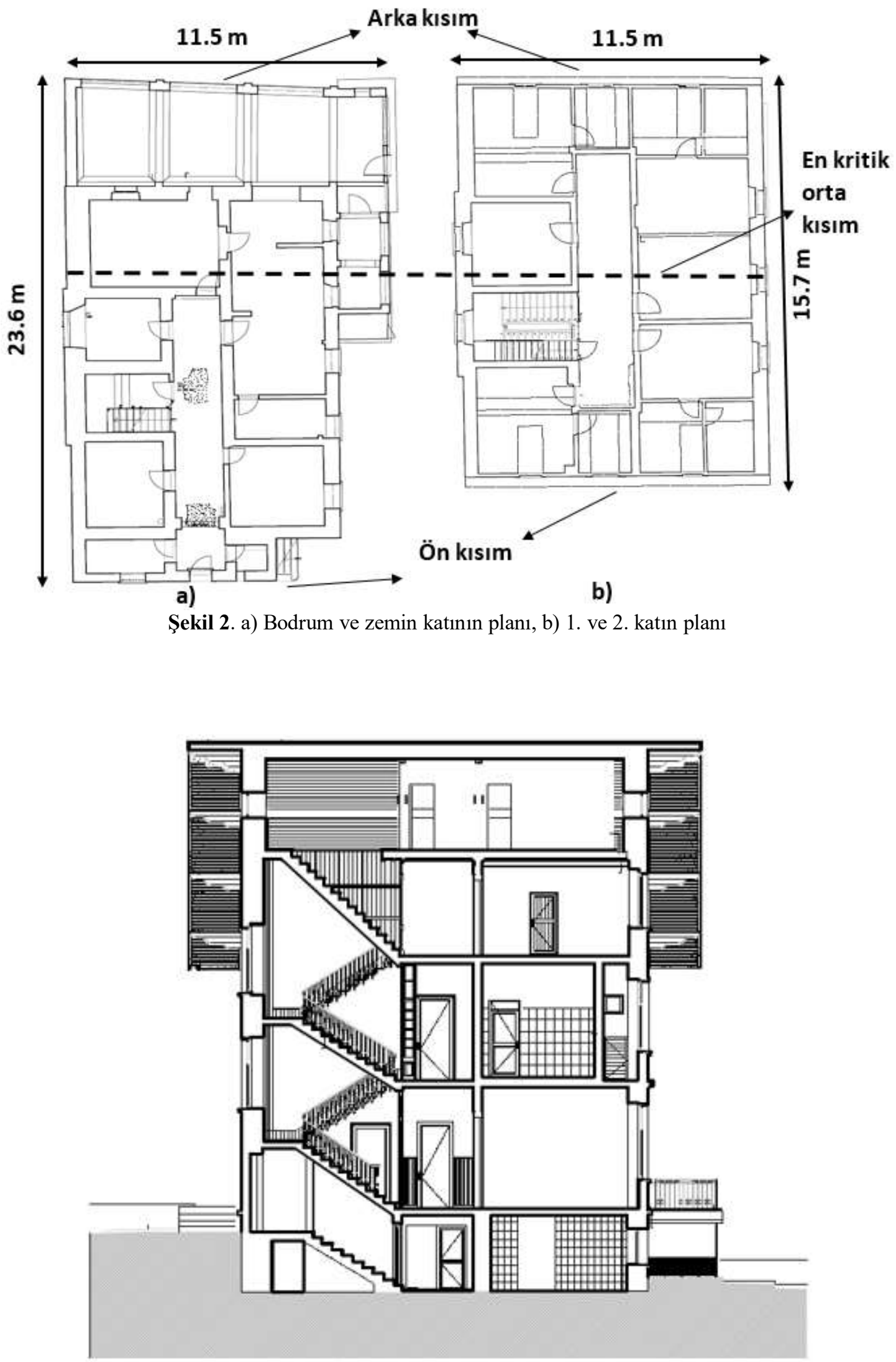

Şekil 3. Konağın ortadan en kritik kesitinin rölevesi 


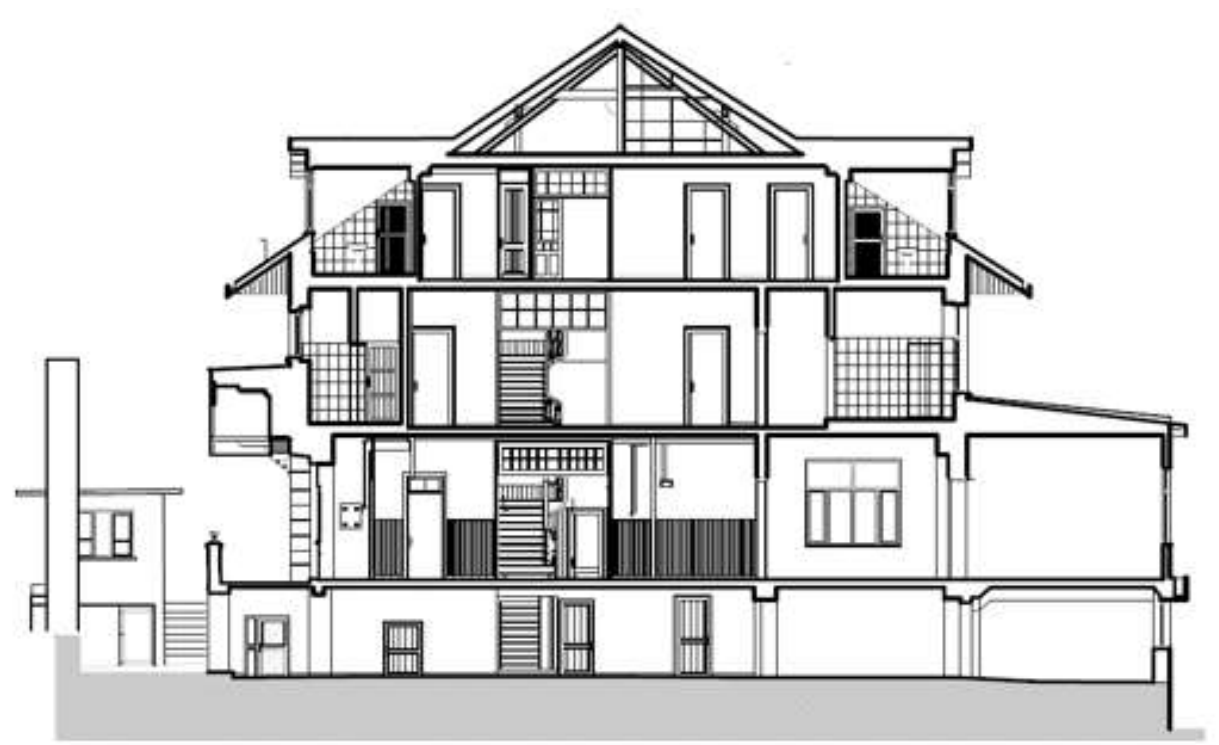

Şekil 4. Konağın arka cepheden rölevesi

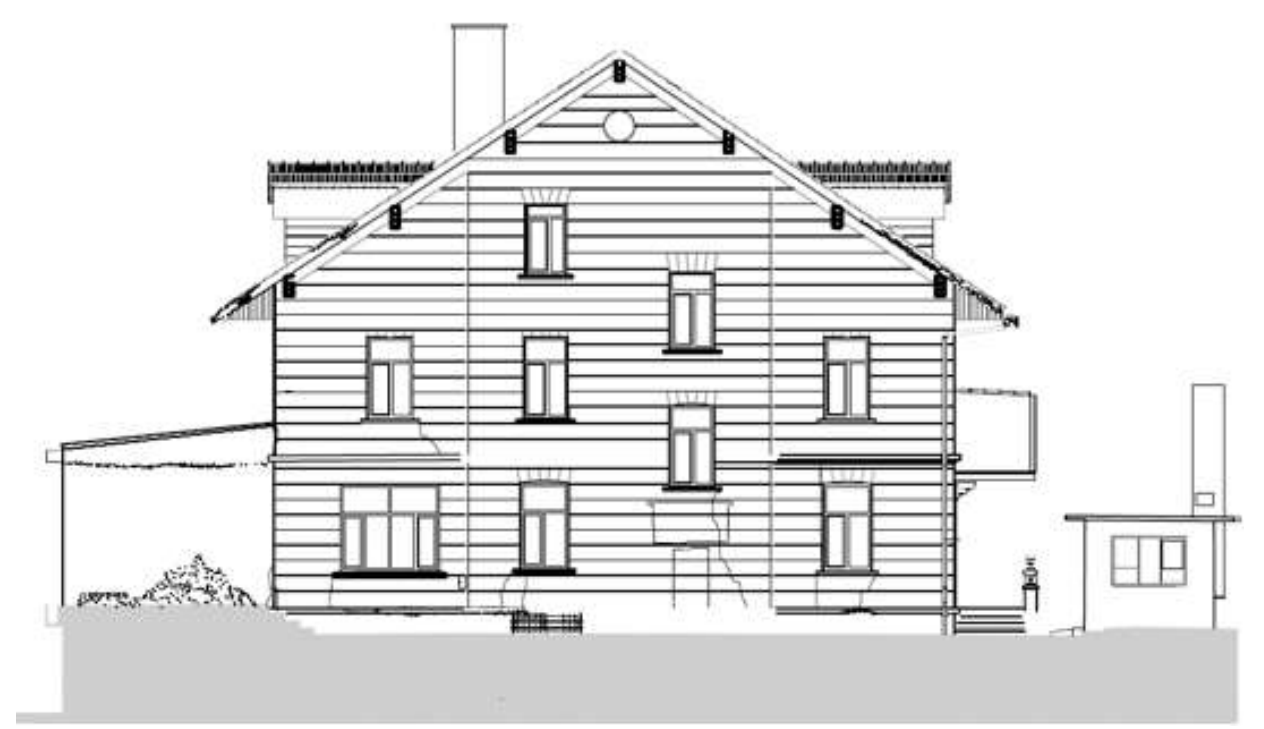

Şekil 5. Konağın ön cepheden rölevesi

\section{Tarihi Rombaki Konağının Üç Boyutlu Modellenmesi}

Tarihi binalar, ülke turizmi için büyük öneme sahip değerlerimizdir. Bu sebeple bu yapıların modellenip mevcut durumunun tahlil edilmesi, yapının geleceği hakkında fikir elde etmek için büyük önem arz etmektedir. Bu bölümde, tarihi rombaki yığma yapısının üç boyutlu modellenmesi detaylı olarak sunulmuştur. Modelleme yapılırken ilk olarak daha binanın önce çıkarılan rölevesi detaylı olarak incelenmiştir. İnceleme sonucunda binanın dayanımı için büyük önem arz eden duvar ve döşemelerin yerleri belirlenmiştir ve hatıl, pencere, kapı gibi yığma yapılar için önemli detayların model içerisindeki konumları detaylı olarak tespit edilmiştir. Bodrum kat duvarlarının diğer katlardaki duvarlara göre daha büyük kalınlıkta imal edildiği gözlemlenmiştir. Bu gözlem sonucu, bina oluşturulurken ne kadar özen ve dikkat gösterildiğinin göstergesidir. Rombaki yığma yapısının genel özellikleri Tablo 1'de sunulmuştur. Tablo 1'e göre bodrum katın kat yüksekliği $240 \mathrm{~cm}$ 'dir. Zemin kat, 1. ve 2. katın kat yükseklikleri sırasıyla $372 \mathrm{~cm}, 362 \mathrm{~cm}$ ve $308 \mathrm{~cm}$ 'dir. Bodrum ve zemin katların duvar sayıları sırasıyla 28 ve $45^{\prime}$ dir. Ayrıca 1. ve 2. katıların duvar sayıları sirasiyla 30 ve 23 'dür. Bodrum ve zemin katın döşeme sayısı 8'dir. 1. ve 2. katların döșeme sayıları ise sırasıyla 6 ve 9'dur. Binada düșey hatıl bulunmamaktadır. Ancak normal hatıl sayısı bodrum katta 9 zemin katta ise 11'dir. Buna ek olarak 1. ve 2. katlarda sirasiyla 7 ve 5 adet normal hatıl bulunmaktadır. Ayrıca bodrum kat, zemin kat, 1. ve 2 . 
katlarda sırasıyla 9, 11, 7 ve 5 adet kapı bulunmaktadır. Bodrum katta hiç pencere bulunmamaktadır. Çünkü bu kat normal yer seviyesinden aşağıdadır. Zemin kat, 1. ve 2. katlarda sırasıyla 16, 16 ve 5 adet pencere bulunmaktadır. Modelleme yapılırken ilk olarak temel kısmı oluşturulmuştur. Bina incelemesi sırasında yapı temelinin sürekli temel olduğu gözlemlenmiştir. Temel modellenirken sürekli temel olarak modelleme yapılmıştır ve her bir taşıyıcı duvarın altına binaya uygun ve projeye uygun temeller tanımlanmıştır. Daha sonra bodrum kat modellenmiştir. Bodrum kattaki dış duvarlar 1 metre kalınlıktadırlar ve bu kalın duvarlar binanın mukavemetini artırmaktadır. Ayrıca iç duvarlar ortalama $40 \mathrm{~cm}$ kalınlıktadır. Her bir duvar bina projesine uygun olarak modellenmiştir. Pencere ve kapılar da ayrıca üç boyutlu model içerisinde ayrıntılı olarak modellenmiştir. Pencere ve kapıların yerden yükseklilerinin gerçek yapıdaki ile aynı olmasına özen gösterilmiştir. Bodrum katın yerden yüksekliği 2.4 metredir. Zemin kat ve diğer katlar ise projeyle bire bir modellenmiştir. Çatı duvarlarına, projeye uygun olarak kenarlardan eğimler verilmiştir. Bu eğim, çatı katında bulunan tüm duvar, pencere ve kapılara da verilmiştir. Tarihi Rombaki konağının üç boyutlu modellenmiş hali Şekil 6'da verilmiştir.

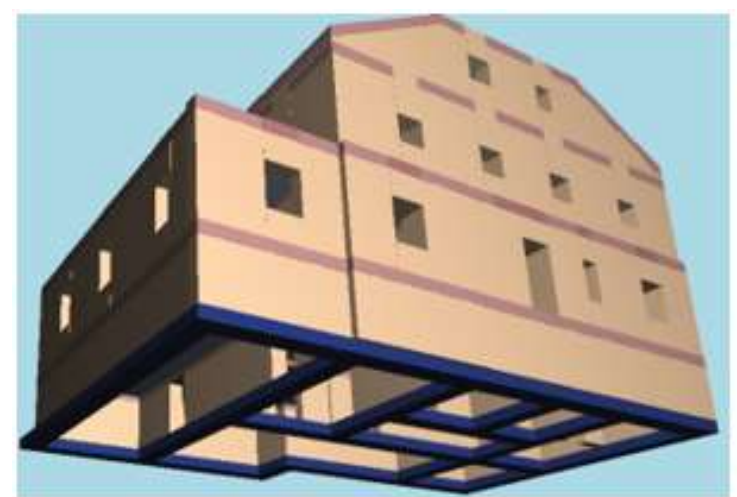

a)

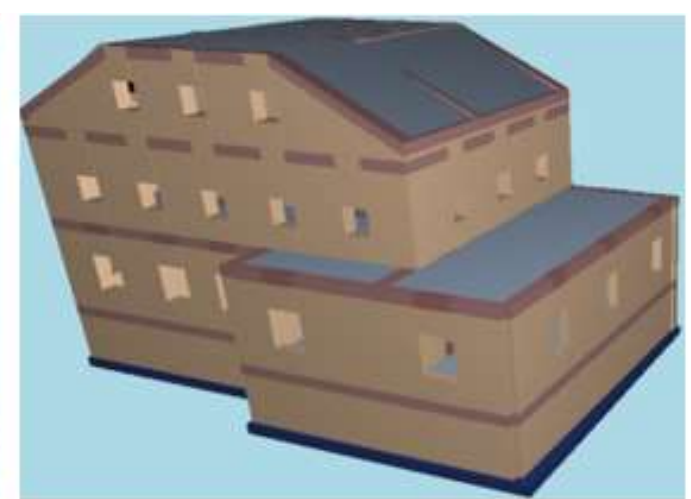

b)

Şekil 6. Konağın 3 boyutlu modellenmiş hali; a) önden görünüş b) arkadan görünüş

Tablo 1. Bina genel özellikleri

\begin{tabular}{ccccc}
\hline Kat İsmi & Bodrum & Zemin & 1.Kat & 2.Kat \\
\hline Kat İndisi & B & Z & 1 & 2 \\
Kat Yüksekliği (m) & 240 & 372 & 362 & 308 \\
Kattaki Duvar Sayısı (Adet) & 28 & 45 & 30 & 23 \\
Döşeme Sayısı (Adet) & 8 & 8 & 6 & 9 \\
Düşey Hatıl Sayıs1 (Adet) & 0 & 0 & 0 & 0 \\
Hatıl Sayısı (Adet) & 9 & 11 & 7 & 5 \\
Kapı Sayısı (Adet) & 9 & 11 & 7 & 5 \\
Pencere Sayısı (Adet) & 0 & 16 & 16 & 5 \\
Manto Sayısı (Adet) & 0 & 0 & 0 & 0 \\
\hline
\end{tabular}

\section{Performans Analizi Sonuçları}

Rombaki tarihi yığma konağının üç boyutlu analiz sonuçları bu bölümde detaylı olarak sunulmuştur. Analizler ilk olarak binanın mevcut hali ile başlanmıştır. Analizlerde sınırlı bilgi düzeyi seçilmiştir. Binanın mevcut hali üç boyutlu olarak modellendikten sonra performans analizi gerçekleştirilmiştir. Performans analizi gerçekleştirilirken 2018 Türk Deprem Yönetmeliği dikkate alınmıştır. Bu yeni yönetmelikte yığma yapıların performans analizleri ile ilgili birçok bilgi sunulmuştur. Bu sebeple bu yeni deprem yönetmeliği ile performans analizinin yapılması bu çalışmanın diğer çalışmalardan farkını ortaya koymaktadır. Analiz sonuçlarına göre binanın mevcut durumu değerlendirilmiştir. Binanın 
mevcut durumuna göre yapının uzun süre ayakta kalamayacağı belirlenmiştir. Binanın mevcut durumu için tüm katların performans sonuçları Şekil 7'de sunulmuştur.

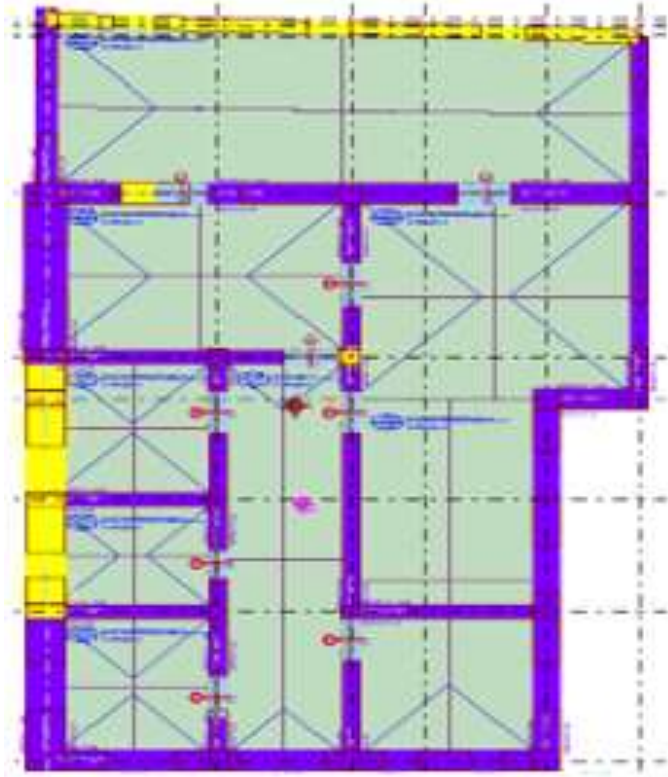

a)

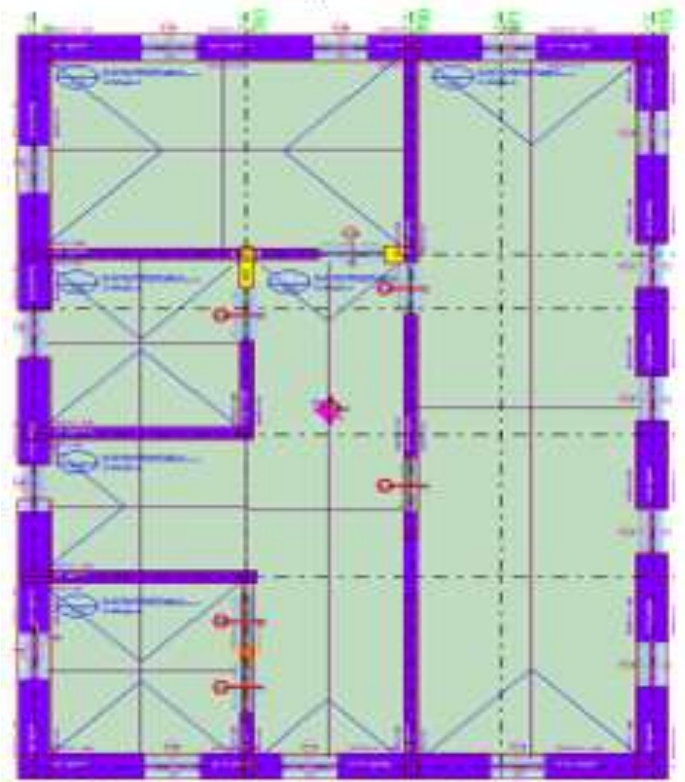

c)

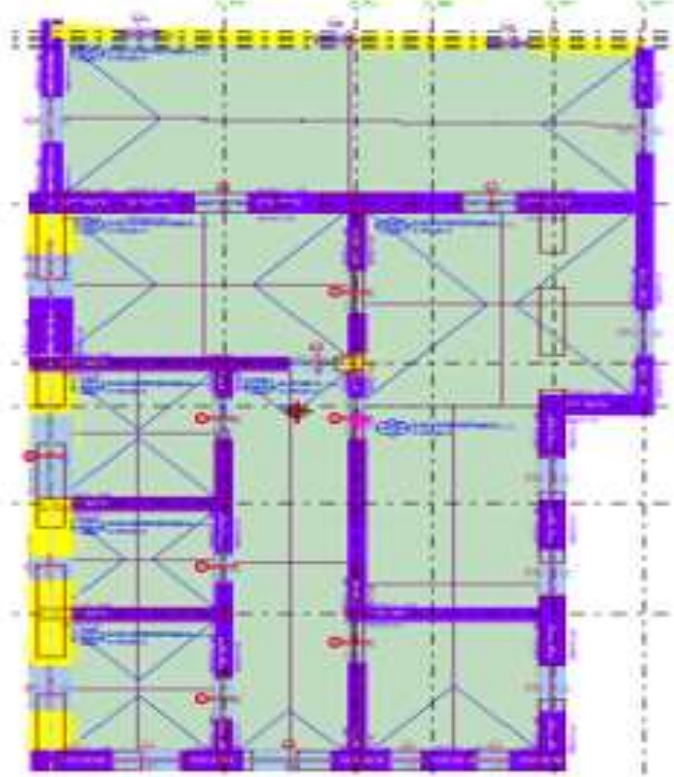

b)

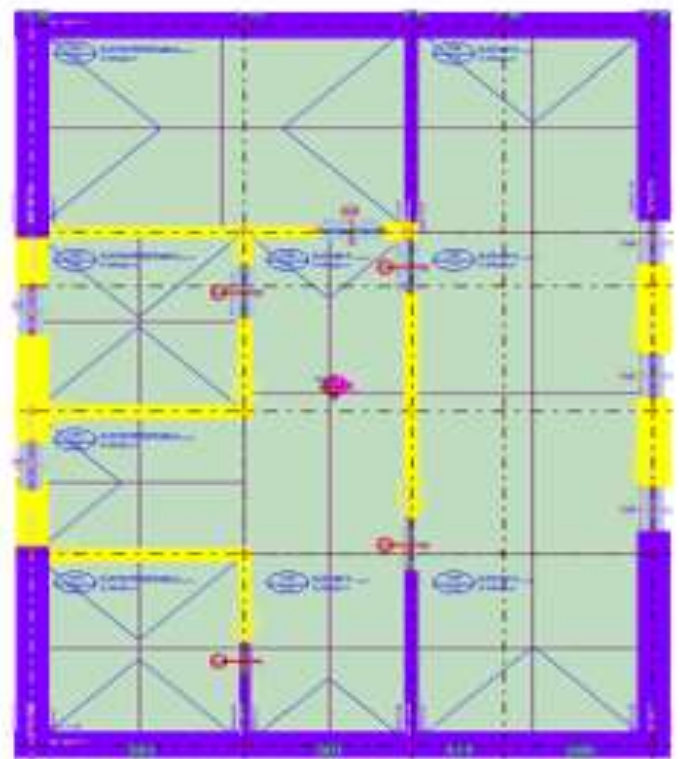

d)

Basınç stresini sağlamayan

\section{Kayma gerilmesi sağlamayan}

\section{Basınç gerilmesi ve kayma gerilmesi sağlamayan}

Şekil 7. a) Bodrum kat için b) Zemin kat için c) 1. kat için d) 2. kat için performans sonuçları

Performans sonuçlarına göre tüm katlardaki duvarlarda kayma gerilmesi problemleri saptanmıştır. Bodrum katta 1 metre kalınlıkta duvarlar olmasına rağmen duvarların çoğunda kayma gerilmesi yönünden olumsuz değerler gözlemlenmiştir. Bu kayma gerilmesi problemleri binanın geleceğini olumsuz yönde etkilemektedir. Zemin katta ise çoğu duvarların kayma gerilmesi yönünden yenildiği tespit edilmiştir. Ayrıca 1. kattaki tüm duvarlarda zemin katta olduğu gibi kayma gerilmesi 
yönünden olumsuz değerler belirlenmiştir. 2. katta ise diğer katlara kıyasla daha az duvarda kayma gerilmesi yönünden yenilmeler gözlemlenmiştir. Bu sonuçlara göre yapının daha fazla ayakta kalamayacağı anlaşılmıştır. Yani deprem güçlendirmesi yapılmasının binanın geleceği açısından daha sağlıklı olabileceği düşünülmüştür. Tablo 2'de ise binanın devrilme performansı detaylı olarak değerlendirilmiştir. Devrilme performansı değerlendirmesi yapının duvarlarının zamanla devrilip devrilmeyeceğinin saptanması için yapılmıştır. Tablo 2'ye göre bodrum kata toplam $37 \times 10^{3} \mathrm{~kg}$ deprem kuvveti etki etmektedir. En fazla deprem yükü zemin kata etki etmektedir ve değeri $118.98 \times 10^{3} \mathrm{~kg}$ ' dir. 1. ve 2. kata ise toplamda sirasiyla $110.18 \times 10^{3} \mathrm{~kg}$ ve $103.72 \times 10^{3} \mathrm{~kg}^{\prime} l \mathrm{k}$ deprem kuvvetleri etki etmektedir. Toplamda binaya $381.32 \times 10^{3} \mathrm{~kg}{ }^{\prime} l 1 \mathrm{k}$ deprem kuvveti etki etmektedir. Katlara etkiyen deprem kuvvetlerinin yere olan yüksekliğiyle elde edilen toplam deprem momenti $3219.81 \times 10^{3} \mathrm{kgm}$ ' dir. Bodrum katta toplam ölü yük $411.98 \times 10^{3} \mathrm{~kg}$ ' dır. En fazla ölü yük zemin katta mevcuttur ve değeri ise $523.81 \times 10^{3} \mathrm{~kg}$ 'dır. Devrilme emniyet hesabı aşağıdaki Formül 1'e göre hesaplanmıştır. Kontroller ise Formül 2, 3, 4, 5’e (2018 Türk Deprem Yönetmeliği 15. Bölüme) göre gerçekleştirilmiş̧tir.

$$
\begin{gathered}
M o=\sum(V i * H i) \\
M o<M a o+X \\
M o<M a o-X \\
M o<M a o+Y \\
M o<M a o-Y
\end{gathered}
$$

Vi deprem kuvvetleri Tablo 2'de detaylı olarak sunulmuştur. VHi değerleri yani Mo değerleri de Tablo 2'de gösterilmiştir. Mo devirmeye çalışan moment değerleri hesaplandıktan sonra devrilmeye karşı koyan momentler performans analizinden elde edilmiştir. Bu sonuçlara göre $+\mathrm{X},-\mathrm{X},+\mathrm{Y},-\mathrm{Y}$ yönlerindeki duvarlarda zamanla devrilme meydana gelmeyeceği saptanmıştır. Duvarlarda kayma yenilmeleri olmasına rağmen zamanla binada devrilmelerin oluşmayacağı belirlenmiştir. Tablo 3 'de ise performans değerlendirmeleri sunulmuştur. Performans değerlerine göre bodrum katına artı ve eksi $x$ yönünde toplam $11.02 \times 10^{3} \mathrm{kgm}$ burulma momenti etki etmektedir ve y yönünde ise toplam $60.77 \times 10^{3}$ kgm burulma momenti meydana gelmektedir. Ayrıca zemin katında x ve y yönünde sırasıyla $99.85 \times 10^{3}$ $\mathrm{kgm}$ ve $482.9 \times 10^{3} \mathrm{kgm}$ burulma momentleri meydana gelmiştir. 1 . kata $\mathrm{x}$ ve y yönünde sirasiyla toplam $11.57 \times 10^{3} \mathrm{kgm}$ ve $-19.9 \times 10^{3} \mathrm{kgm}$ burulma momenti oluşmuştur. Son olarak 2 . katta ise sirasiyla toplam $-8.2 \times 10^{3} \mathrm{kgm}$ ve $13.8 \times 10^{3} \mathrm{kgm}$ burulma momenti meydana gelmiştir. Duvar kesme kuvveti taşıma kapasitesi bodrum kat için x ve y yönünde sırasıyla $144.65 \times 10^{3} \mathrm{~kg}$ ve $229.56 \times 10^{3} \mathrm{~kg}$ ' dır (Tablo 3). Zemin katta ise bu değer x ve y yönünde sirasıyla $50.72 \times 10^{3} \mathrm{~kg}$ ve $130.1 \times 10^{3} \mathrm{~kg}$ ' dır. 1 . katta duvar kesme kuvveti taşıma kapasitesi x yönünde $11.57 \times 10^{3} \mathrm{~kg}$ ' dır ve y yönünde ise $-19.9 \times 10^{3} \mathrm{~kg}$ ' dır. Son olarak 2. Katta bu değer x ve y yönünde sirasılyla $-8.2 \times 10^{3} \mathrm{~kg}$ ve $13.8 \times 10^{3} \mathrm{~kg}$ 'dır. Kesme kapasitesi yetersiz duvar sayısı Tablo 3'de detaylı olarak sunulmuştur. Bu sayı bodrum katta $\mathrm{x}$ ve y yönünde sırasıyla 9 ve 13'tür. Ayrıca zemin katta kesme kapasitesi yetersiz duvar sayısı x ve y yönünde sırasıyla 14 ve 18 'dir. 1 . Katta ise bu değer aynı yönlerde 11 ve 16 'dır. Son olarak 2 . Katta ise bu değer x ve y yönlerinde sırasıyla 2 ve 7'dir. Bu değerlerden de görüldüğ̈ gibi en fazla kesme kapasitesi yetersiz duvar zemin katta mevcuttur. Kapasitesi yetersiz duvarlara gelen toplam kesme kuvveti bodrum katta $\mathrm{x}$ ve y yönlerinde $381.32 \times 10^{3} \mathrm{~kg}$ 'dır. Bu değer zemin katta ise $\mathrm{x}$ ve y yönlerinde $344.32 \times 10^{3} \mathrm{~kg}$ ' dır. Ayrıca kapasitesi yetersiz duvarlara gelen toplam kesme kuvveti 1. kattaki x ve y yönleri için sırasıyla $225.34 \times 10^{3} \mathrm{~kg}$ ve $224.66 \times 10^{3} \mathrm{~kg}$ ' dır. Son olarak bu değer 2 . katta $\mathrm{x}$ ve y yönlerinde sirasıyla $113.56 \times 10^{3}$ $\mathrm{kg}$ ve $97.63 \times 10^{3} \mathrm{~kg}$ ' dır. Dayanımı yetersiz duvarların kat kesme kuvvetine katkısı bodrum ve zemin katta $x$ ve y yönünde sirasıyla $100 \times 10^{3} \mathrm{~kg}$ ' dır. 1 . katta $\mathrm{x}$ ve y yönünde bu değer sirasıyla $100 \times 10^{3} \mathrm{~kg}$ ve $99.7 \times 10^{3} \mathrm{~kg}$ 'dır. Son olarak bu değer 2 . katta x ve y yönünde sirasıyla $98.6 \times 10^{3} \mathrm{~kg}$ ve $84.8 \times 10^{3} \mathrm{~kg}$ ' dır. Tablo 4'de ise depremden dolay1 katlara gelen kesme kuvveti değerleri sunulmuştur. Bodrum ve zemin katlarda bu değer sirasıyla $381.32 \times 10^{3} \mathrm{~kg}$ ve $344.32 \times 10^{3} \mathrm{~kg}$ 'dır. Ayrıca 1 . ve 2 . katta bu değer sirasiyla $225.34 \times 10^{3} \mathrm{~kg}$ ve $115.16 \times 10^{3} \mathrm{~kg}$ 'dır. Bu değerlere göre katlara gelen kesme kuvveti değerleri en fazla bodrum katta meydana gelmiştir. 
Tablo 2. Devrilme Momenti Kontrolü

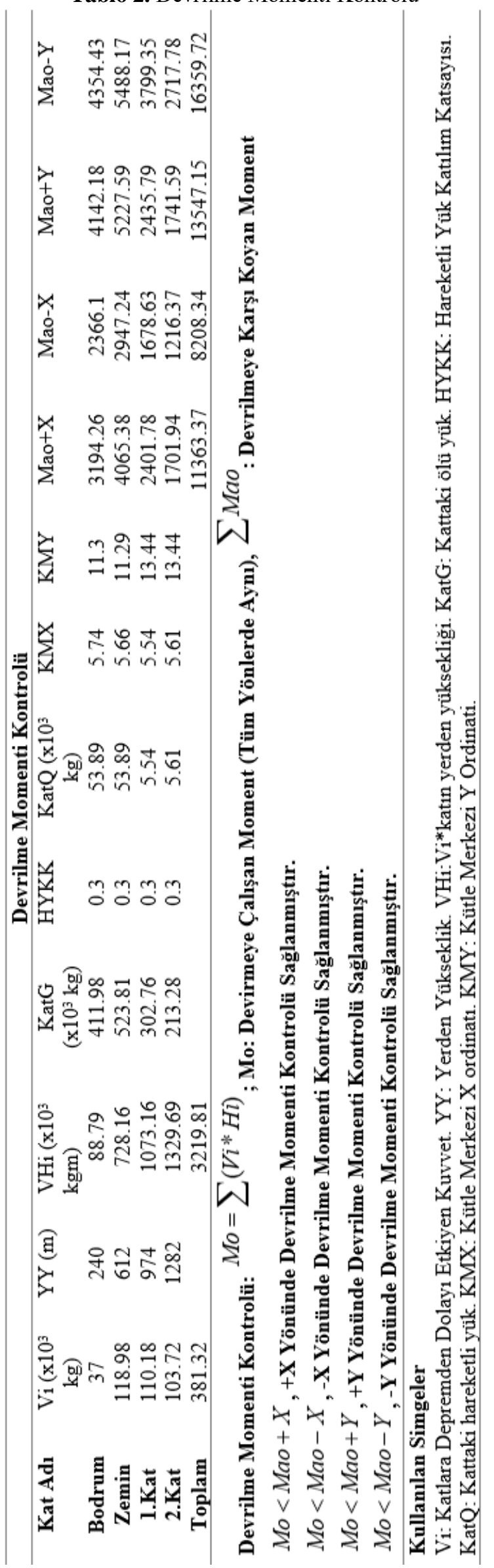


Tablo 3. Performans Değerlendirilmesi

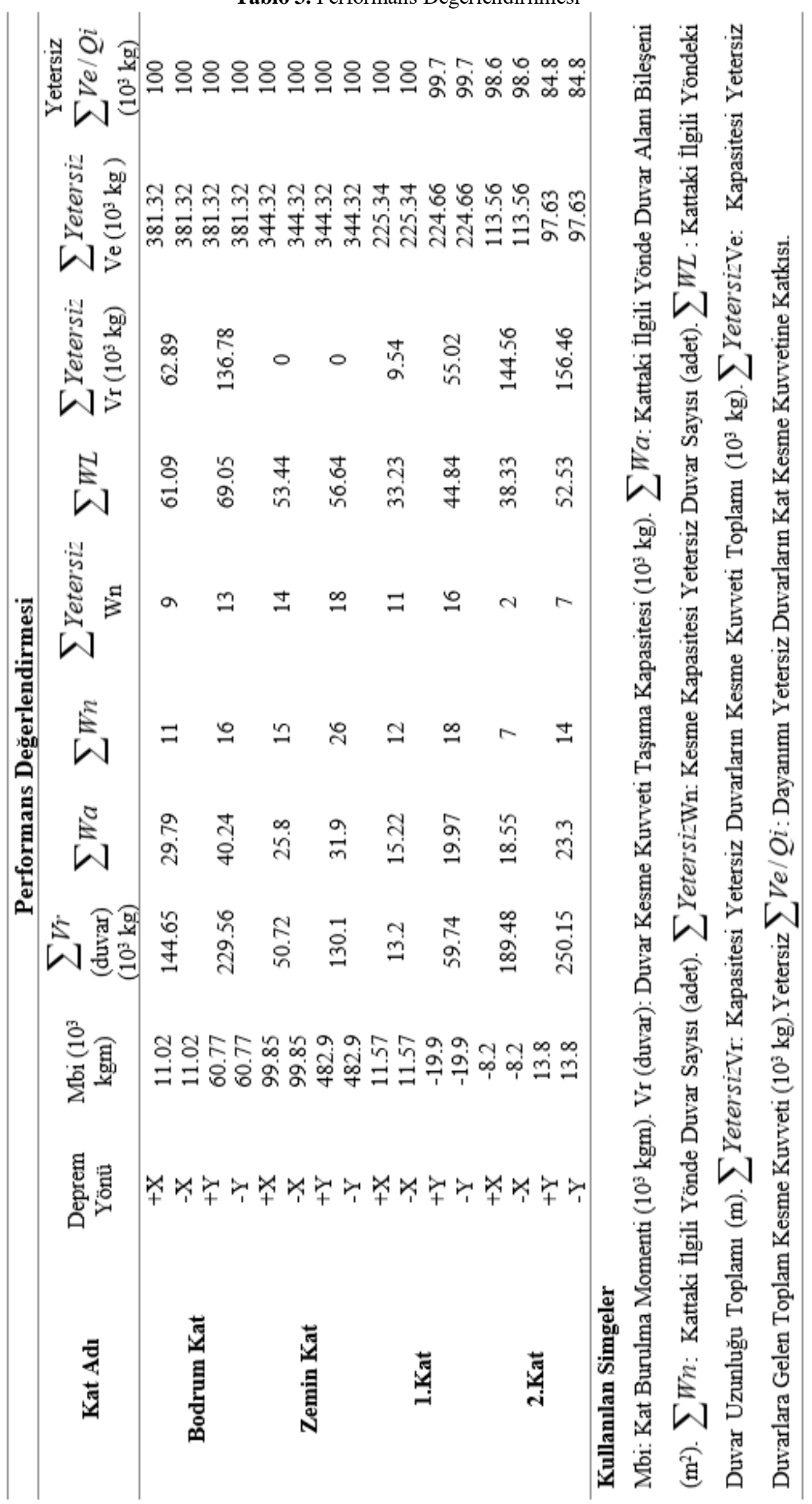


Tablo 4. Depremden dolayı katlara gelen kesme kuvveti

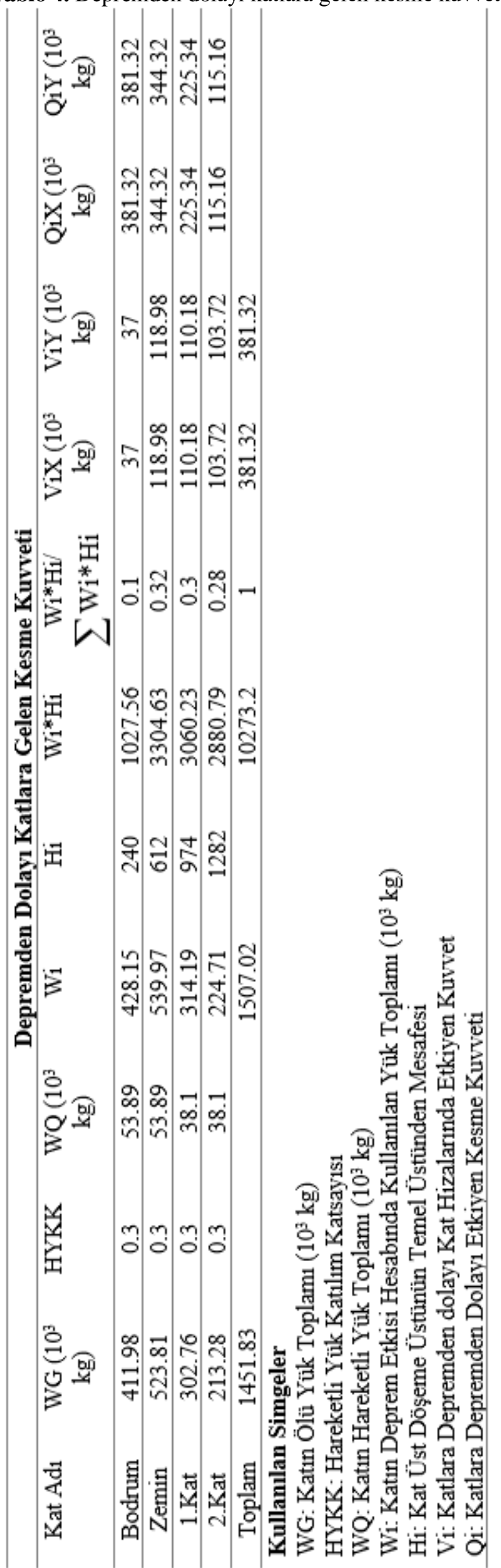


Binanın mevcut durumu için performans analizi gerçekleştirildikten sonra güçlendirme yapılması gereken yerler tespit edilmiştir. Bu tespit sonucunda binanın dış duvarlarının çoğunun mantolama yapılması gerektiğine karar verilmiştir. Bu mantolama işlemi sürekli donatı, ankraj çubuğu, çelik hasır ve beton malzemeleri ile gerçekleştirilmiştir. Mantolama işlemi sırasında tarihi yapının dokusuna zarar verilmemesine dikkat edilmiştir. Kalın mantolama yerine yapıya en az hasar verecek manto kalınlığı seçilmiştir. Rombaki yığma yapısına yapılan manto örneği Şekil 8'de detaylı olarak gösterilmiştir. Yapıya yerleştirilen ankraj çubuklarının olabildiğince küçük ve az sayıda olmasına dikkat edilmiştir. Mantolama işlemi ilk olarak binanın dış duvarlarından başlanmıştır. Kalın duvarlara mantolama yapılırken pencere ve hatıllara dikkat edilmiştir. Her bir pencerenin mantolama sırasında hasar görmemesi ve pencerenin kapanmaması bu çalışma için öncelik olmuştur. Şekil 9'da ise binanın mantolanmış 3 boyutlu görünümü sunulmuştur. Binanın 2. katı, çatı eğimine uygun olarak mantolanmıştır. Her bir mantolama işlemi bu eğim kuralarına uyularak gerçekleştirilmiştir.

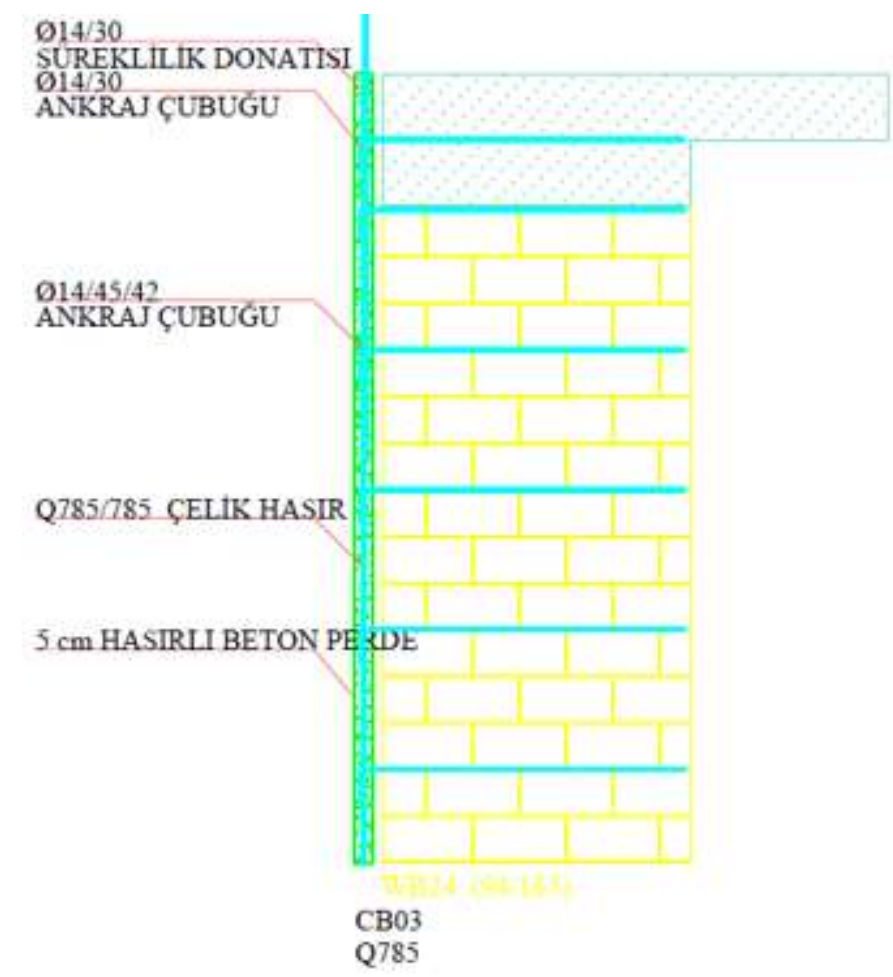

Şekil 8. Mantolanmış duvar örneği

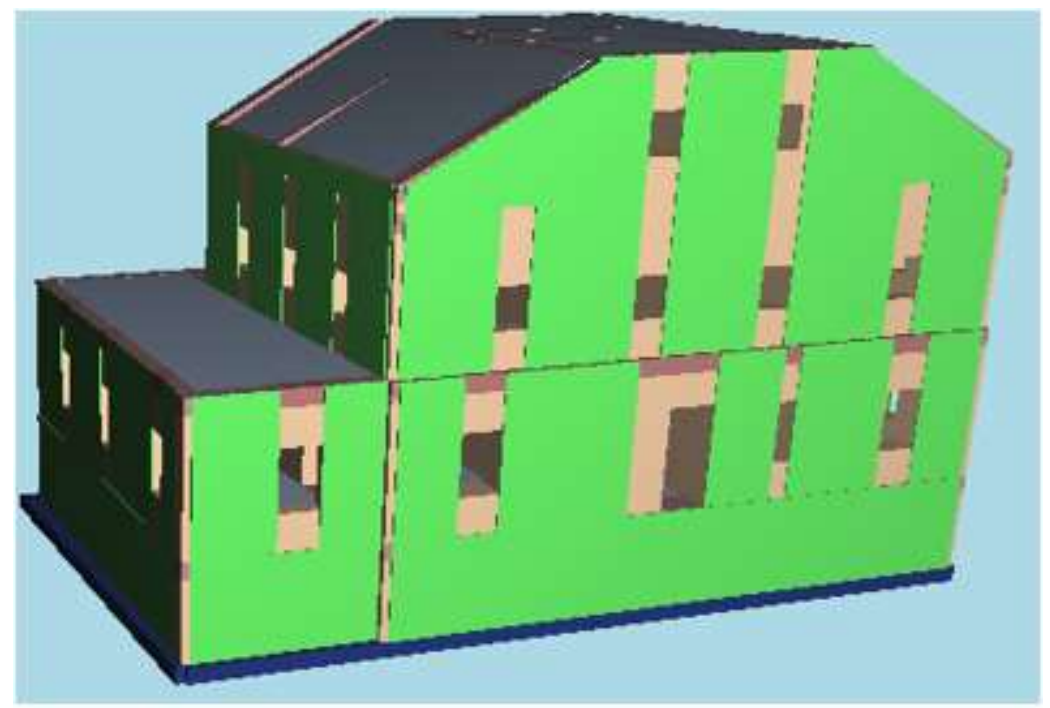

Şekil 9. Mantolanmış konağın 3 boyutlu hali 

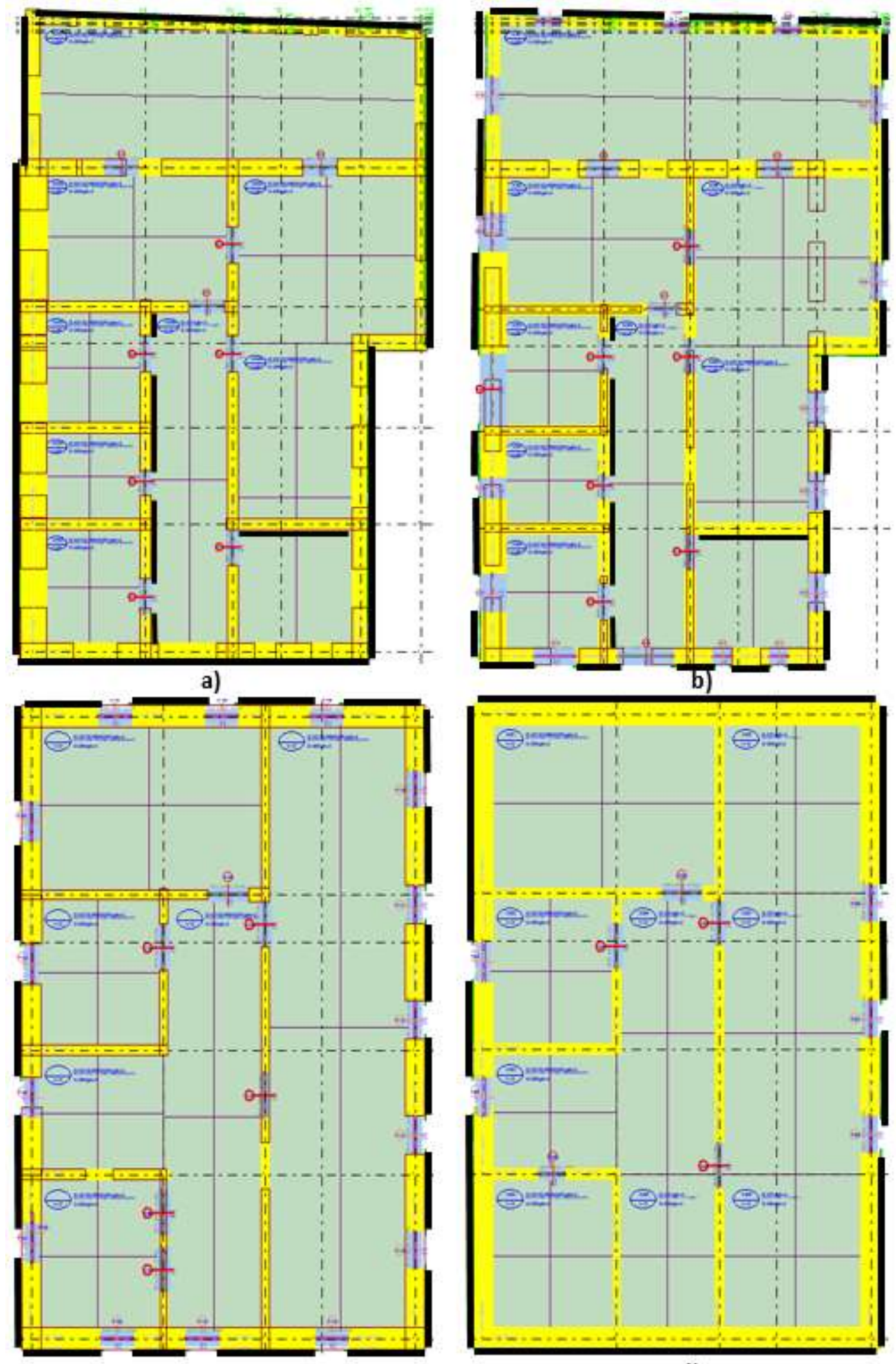

c)
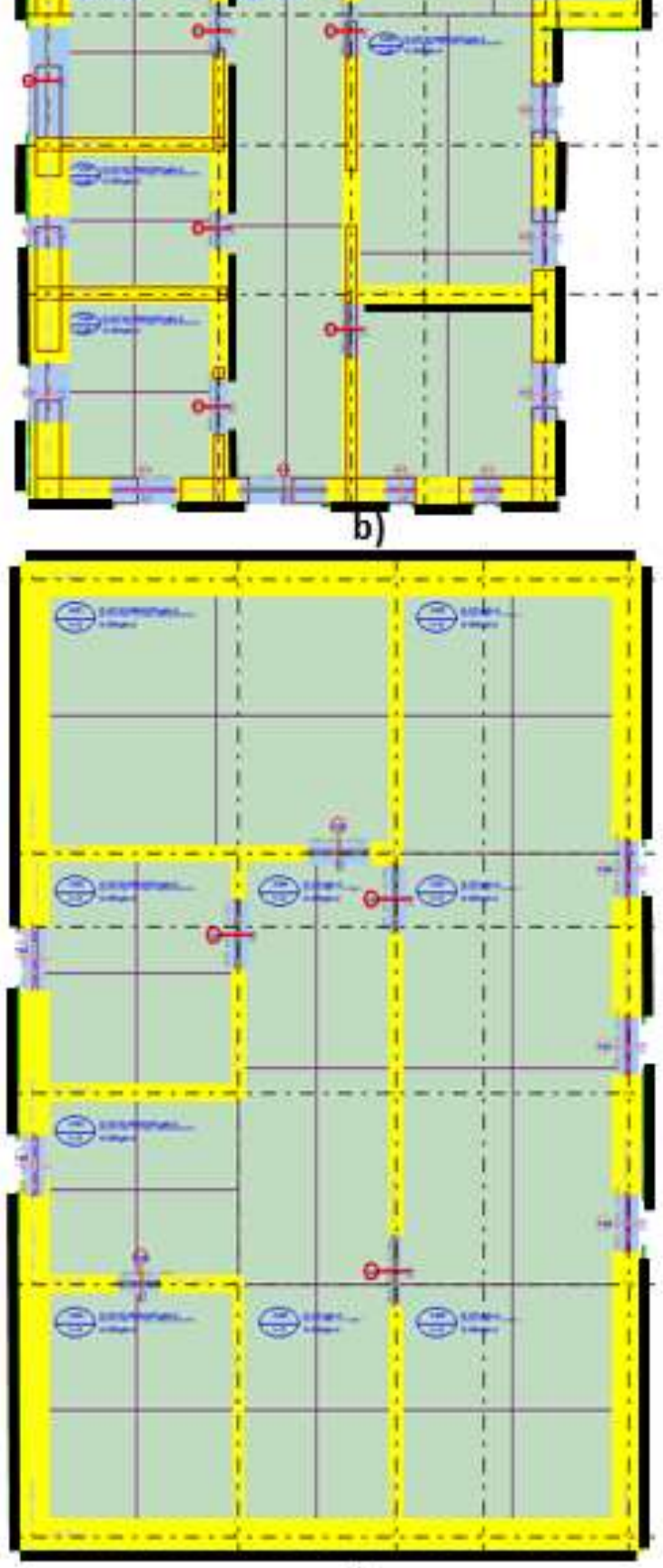

d)

Şekil 10. Konağın performans analizine göre mantolama durumu 
Binanın duvarlarının mantolanmış hali ise Şekil 10'da detaylı olarak sunulmuştur. Siyah gösterilen çizgiler mantolamanın yapıldığı yerleri temsil etmektedir. Her bir manto için ayrı bir siyah çizgi çizilmiştir ve her bir kat için ayrı ayrı gösterilmiştir. Pencerelerin mantolama sırasında nasıl korunduğu Şekil 10' da görülmektedir. İlk olarak analizler binanın dış duvarlarının mantolanmış haliyle yapılmıştır. Sadece dış taşıyıcı duvarların mantolanmasından dolayı analiz sonucunda iç duvarların bir kısmının yakın gelecekte yenilmeye uğrayacağı gözlemlenmiştir. Daha sonra yenilme yaşanan iç duvarların bir kısmına da mantolama yapılarak binanın tamamının gelecekte emniyetle ayakta kalması sağlanmıştır. Bu çalışmada mantolamanın tarihi yapıların emniyetine katkısına ek olarak tarihi dokusunu bozmak gibi bir dezavantajının olması da göz önünde bulundurulmuştur. Bu sebeple bu çalışmada tarihi dokunun korunması ilk öncelik olmuştur. Mantolama sonrası binanın performansı Tablo 5'de sunulmuştur. Tablo 5'e göre bodrum katında toplam 16 duvara manto yapılmıştır. Bu sayı zemin katında 36'ya çıkmıştır. 1. ve 2. katlarda ise mantolanmış duvar sayısı sırasıyla 23 ve 12 'dir. Binaya mantolama yapılırken beton cinsi olarak C25 betonu kullanılmıştır. Tablo 5 incelendiğinde mevcut duvarların birim hacim ağırlıklarının $1500 \mathrm{~kg} / \mathrm{m}^{3}$ olduğu görülmektedir. Ayrıca duvar çatlama emniyet gerilmesi $0.25 \mathrm{MPa}$ olduğu tespit edilmiştir. Duvarların elastisite modüllerinin ise $800 \mathrm{MPa}$ olduğu saptanmıştır. Tablo 6'da ise devrilme momenti kontrolü yapılmıştır. Tabloya göre katlara depremden dolayı etkiyen kuvvet bodrum katı için $39.27 \times 10^{3} \mathrm{~kg}$ 'dır. Zemin kat için ise bu değer $126.13 \times 10^{3} \mathrm{~kg}$ ' dir. Ayrica katlara depremden dolayı etkiyen kuvvet 1. ve 2. kat için sırasıyla $117.57 \times 10^{3}$ $\mathrm{kg}$ ve $108.65 \times 10^{3} \mathrm{~kg}$ 'dır. Bu değerlerden de görüldüğü gibi en fazla deprem kuvveti zemin kata gelmiştir. Devrilme emniyet hesabı aşağıdaki Formül 6'ya göre hesaplanmıştır. Kontroller ise Formül 7, 8, 9 ve 10’a (2018 Türk Deprem Yönetmeliği 15. Bölüme) göre yapılmıştır.

$$
\begin{aligned}
M o & =\sum(V i * H i) \\
M o & <M a o+X \\
M o & <M a o-X \\
M o & <M a o+Y \\
M o & <M a o-Y
\end{aligned}
$$

Bu denklemlere göre binada mantolandıktan sonra devrilmeye karşı oluşan moment her kat için ayr1 ayrı hesaplanmıştır. Bu değer bodrum katı için $+\mathrm{X}$ yönünde $3614.82 \times 10^{3} \mathrm{kgm}$ 'dir. Ayrıca devrilmeye karş1 oluşan moment zemin kat için $4557.33 \times 10^{3} \mathrm{kgm}$ 'dir. 1. ve 2. kat için $+\mathrm{X}$ yönünde sirasıly $2722.44 \times 10^{3} \mathrm{kgm}$ ve $1906.17 \times 10^{3} \mathrm{kgm}$ 'dir. Tam tersi yönde yani $-\mathrm{X}$ yönünde bodrum katta devrilmeye karşı oluşan moment $2769.84 \times 10^{3} \mathrm{kgm}$ ' dir. Aynı yönde bu değer zemin kat için $3485.33 \times 10^{3}$ kgm'dir. 1. ve 2. kat için ise sırasıyla $1988.06 \times 10^{3} \mathrm{kgm}$ ve $1401.14 \times 10^{3} \mathrm{kgm}$ ' dir. Bu değerlere göre $+\mathrm{X}$ ve $-X$ yönlerinde devrilmeye karşı koyan en büyük moment zemin katta meydana gelmiştir. Ayrıca $+Y$ yönünde bu moment değeri bodrum kat için $4448 \times 10^{3} \mathrm{kgm}$ 'dir. Zemin kat için ise $5613.38 \times 10^{3} \mathrm{kgm}$ ' dir (Tablo 6). Bu moment değeri 1. ve 2. katlar için ise sirasiyla $2636.77 \times 10^{3} \mathrm{kgm}$ ve $1818.85 \times 10^{3} \mathrm{kgm}$ ' dir. Tam tersi yönde yani $-Y$ yönünde ise bodrum katta 4600x $10^{3} \mathrm{kgm}$ devrilmeye karşı moment meydana gelmiştir. Ayrıca zemin katta ise $5784.25 \times 10^{3} \mathrm{kgm}^{3}$ moment oluşmuştur. Son olarak 1. ve 2. katta $4038.7 \times 10^{3} \mathrm{kgm}$ ve $2868.1 \times 10^{3} \mathrm{kgm}$ momentler meydana gelmiştir. 4 yön birbiri ile karşılaştırıldığında en fazla devrilmeye karşı koyan momentin -Y yönünde meydana geldiği gözlemlenmiştir (Tablo 6). Tablo 7'de ise depremden dolayı katlara gelen kesme kuvvetleri tablo halinde sunulmuştur. Bu tabloya göre bodrum kata $403.73 \times 10^{3} \mathrm{~kg}$ 'lık bir kuvvet etki etmektedir. Ayrıca bu kuvvet değeri zemin katta $364.46 \times 10^{3} \mathrm{~kg}$ 'dir. 1 . ve 2 . katlarda ise depremden dolayı katlara gelen kesme kuvveti değerleri $238.33 \times 10^{3} \mathrm{~kg}$ ve $120.76 \times 10^{3} \mathrm{~kg}$ ' dır. Bu değerler hem $\mathrm{X}$ hem de $\mathrm{Y}$ yönü için de geçerlidir. Tablo 8 'de binanın mantolama işlemi yapıldıktan sonraki performans sonuçları sunulmuştur. $\mathrm{Bu}$ performans sonuçları binanın mevcut durumu ile karşılaştırıldığında, mevcut durumdaki kapasitesi yetersiz duvarların ve kesme emniyetini sağlamayan duvarların mantolama işleminden sonra yeterli hale geldikleri görülmektedir. $\mathrm{Bu}$ sonuç ile mantolama işleminin binanın servis ömrünü uzattığ kanıtlanmıştır. Şekil 11'de binanın mevcut durumu ile güçlendirilmiş durumu arasında grafiksel olarak karşılaştırma yapılmıştır. $+\mathrm{X},-\mathrm{X},+\mathrm{Y}$ ve $-\mathrm{Y}$ yönleri için oluşturulan grafiklere göre mantolama işleminden sonra devrilmeye karşı koyan momentin açık bir şekilde arttığı görülmektedir. Yükseklik 
boyunca her katta moment değerleri farklıdır ve en çok devrilme momentine karşı koyan moment zemin kat seviyesinde meydana gelmiştir. Ayrıca depremden dolayı katlara gelen kesme kuvveti-kat yüksekliği grafiği binanın mevcut durumu ve güçlendirme sonrası durumu için karşılaştırmalı olarak Şekil 12'de sunulmuştur. Bu grafiğe göre mantolama işleminden sonra katlara gelen kesme kuvveti değerleri bariz bir şekilde artmıştır.

Tablo 5. Binanın genel durumu

\begin{tabular}{ccccccccccc}
\hline $\begin{array}{c}\text { Kat } \\
\text { Ismi }\end{array}$ & $\begin{array}{c}\text { Kat } \\
\text { Indisi }\end{array}$ & $\begin{array}{c}\text { Kat } \\
\text { Yüksekliği }\end{array}$ & $\begin{array}{c}\text { Hareketli } \\
\text { Yük } \\
\text { Katılım } \\
\text { Katsayısı }\end{array}$ & $\begin{array}{c}\text { Kattaki } \\
\text { Duvar } \\
\text { Sayısı } \\
\text { (Adet) }\end{array}$ & $\begin{array}{c}\text { Döşeme } \\
\text { Sayıs } \\
\text { (Adet) }\end{array}$ & $\begin{array}{c}\text { Düșey } \\
\text { Hatıl } \\
\text { Sayısı } \\
\text { (Adet) }\end{array}$ & $\begin{array}{c}\text { Hatıl } \\
\text { Sayıs } \\
\text { (Adet) }\end{array}$ & $\begin{array}{c}\text { Kapı } \\
\text { Sayıs } \\
\text { (Adet) }\end{array}$ & $\begin{array}{c}\text { Pencere } \\
\text { Sayısı } \\
\text { (Adet) }\end{array}$ & $\begin{array}{c}\text { Manto } \\
\text { Sayısı } \\
\text { (Adet) }\end{array}$ \\
\hline Bodrum & B & 240 & 0.3 & 28 & 8 & 0 & 9 & 9 & 0 & 16 \\
Zemin & Z & 372 & 0.3 & 45 & 8 & 0 & 25 & 11 & 16 & 36 \\
1.Kat & 1 & 362 & 0.3 & 30 & 6 & 0 & 21 & 7 & 16 & 23 \\
2.Kat & 2 & 308 & 0.3 & 23 & 9 & 0 & 10 & 5 & 5 & 12 \\
\hline
\end{tabular}

Duvarların Birim hacim Ağırlıkları $\left(\mathrm{kg} / \mathrm{m}^{3}\right): 1500$

Duvar Çatlama Emniyet Gerilmesi (MPa): 0.25

Elastisite Modülü (MPa): 800

Tablo 6. Devrilme momenti kontrolü tablosu

\begin{tabular}{|c|c|c|c|c|c|c|c|c|c|c|c|c|}
\hline \multicolumn{13}{|c|}{ Devrilme Momenti Kontrolü } \\
\hline Kat Adı & $\begin{array}{c}\mathrm{Vi} \\
\left(10^{3} \mathrm{~kg}\right)\end{array}$ & $\begin{array}{l}\mathrm{YY} \\
(\mathrm{cm})\end{array}$ & VHi & KatG & HYKK & KatQ & $\mathrm{KMX}$ & KMY & $\mathrm{Mao}+\mathrm{X}$ & Mao-X & $\mathrm{Mao}+\mathrm{Y}$ & Mao-Y \\
\hline Bodrum & 39.27 & 240 & 94.24 & 437.71 & 0.3 & 53.89 & 5.78 & 11.26 & 3614.82 & 2769.84 & 4448 & 4600 \\
\hline Zemin & 126.13 & 612 & 771.92 & 555.57 & 0.3 & 53.89 & 5.77 & 11.24 & 4557.33 & 3485.33 & 5613.38 & 5784.25 \\
\hline 1.Kat & 117.57 & 974 & 1145.12 & 323.43 & 0.3 & 38.1 & 5.6 & 13.4 & 2722.44 & 1988.06 & 2636.77 & 4038.7 \\
\hline 2.Kat & 108.65 & 1282 & 1392.9 & 223.68 & 0.3 & 38.1 & 5.62 & 13.55 & 1906.17 & 1401.14 & 1818.85 & 2868.1 \\
\hline Toplam & 403.73 & & 3404.17 & & & & & & 12800.77 & 9644.38 & 14517 & 17291.06 \\
\hline
\end{tabular}

Devrilme Momenti Kontrolü: $M O=\sum\left(V i^{*} H i\right)$; Mo: Devirmeye Çalıșan Moment (Tüm Yönlerde Aynı),

$\sum M a c$ : Devrilmeye Karşı Koyan Moment

$M o<M a o+X,+X$ Yönünde Devrilme Momenti Kontrolü Sağlanmıștır.

$M o<M a o-X$, -X Yönünde Devrilme Momenti Kontrolü Sağlanmıștır.

$M o<M a O+Y,+Y$ Yönünde Devrilme Momenti Kontrolü Sağlanmıştır.

$M o<M a o-Y$, -Y Yönünde Devrilme Momenti Kontrolü Sağlanmıștır.

\section{Kullanılan Simgeler}

Vi: Katlara Depremden Dolay1 Etkiyen Kuvvet.

YYi: Yerden Yükseklik.

HYKK: Hareketli Yük Katılım Katsayısı.

KMX: Kütle Merkezi X ordinati.

KMY: Kütle Merkezi Y Ordinati. 
Tablo 7. Depremden dolayı katlara gelen kesme kuvveti

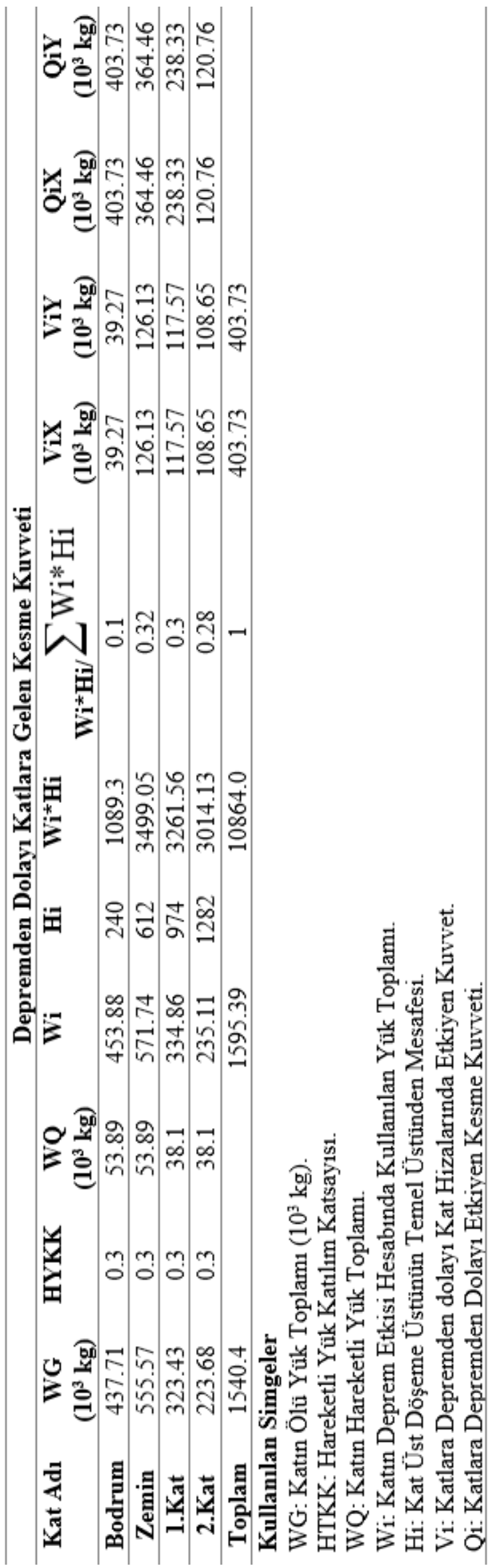


Tablo 8. Performans değerlendirmesi

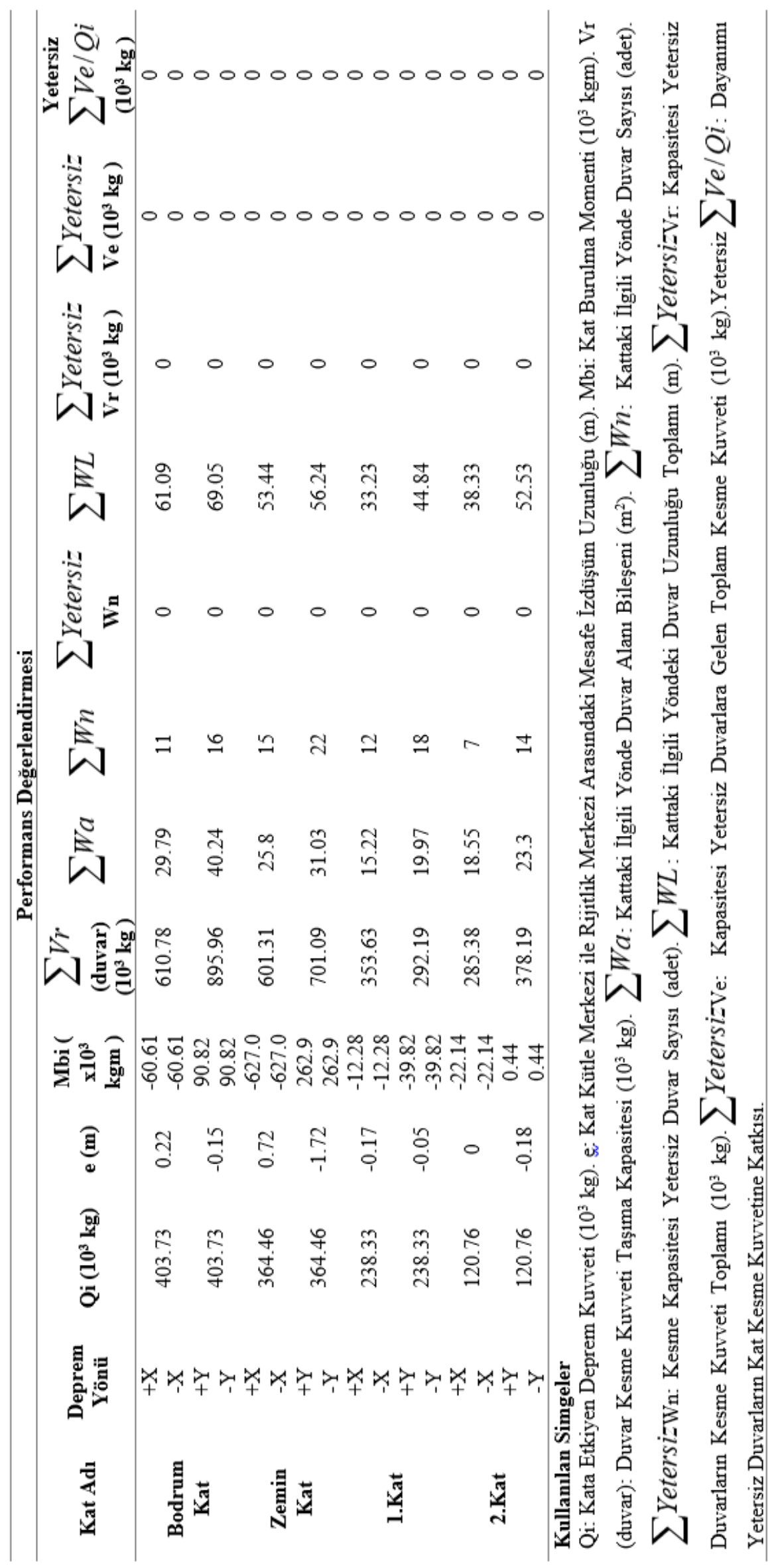




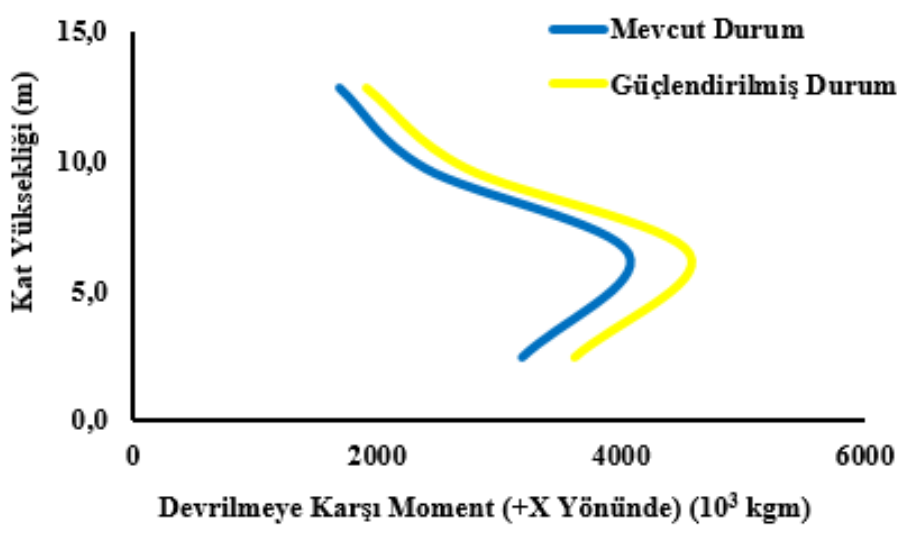

a)

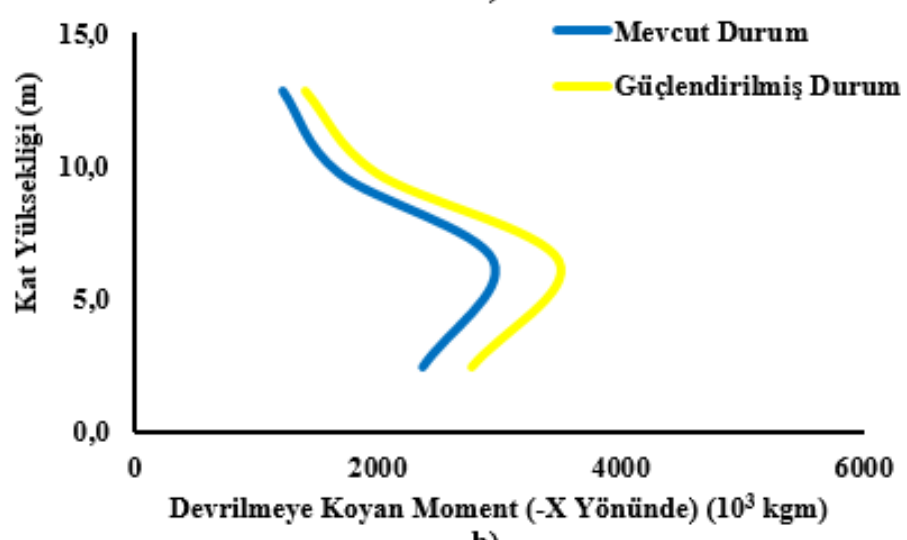

b)

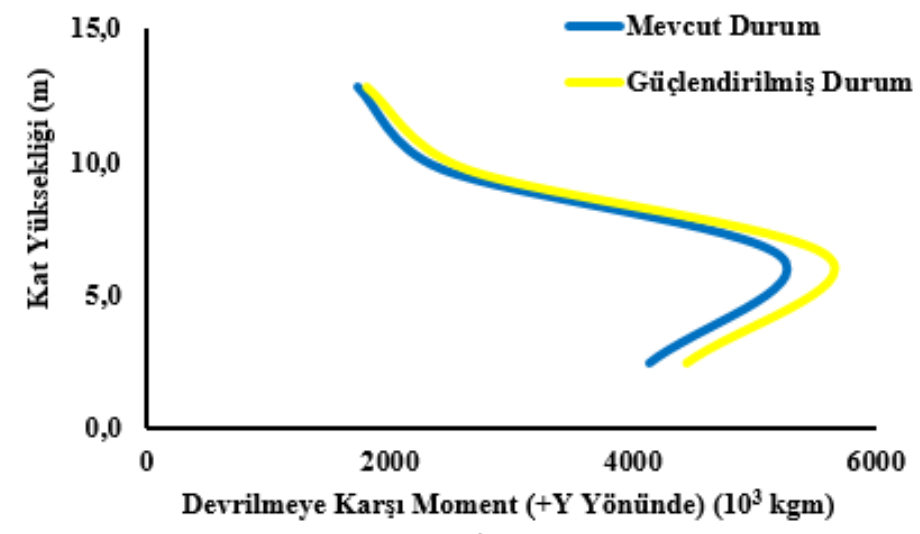

c)

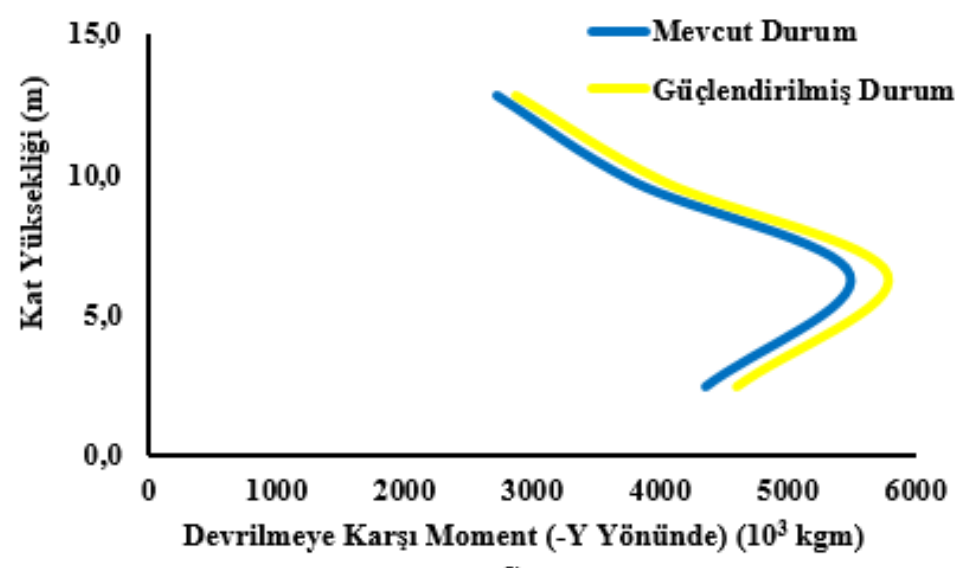

d)

Şekil 11. Devrilmeye karşı koyan moment-kat yüksekliği grafikleri a) $+X$ yönünde b) $-X$ yönünde c) $+Y$ yönünde $\mathrm{d}$ ) $-\mathrm{Y}$ yönünde 


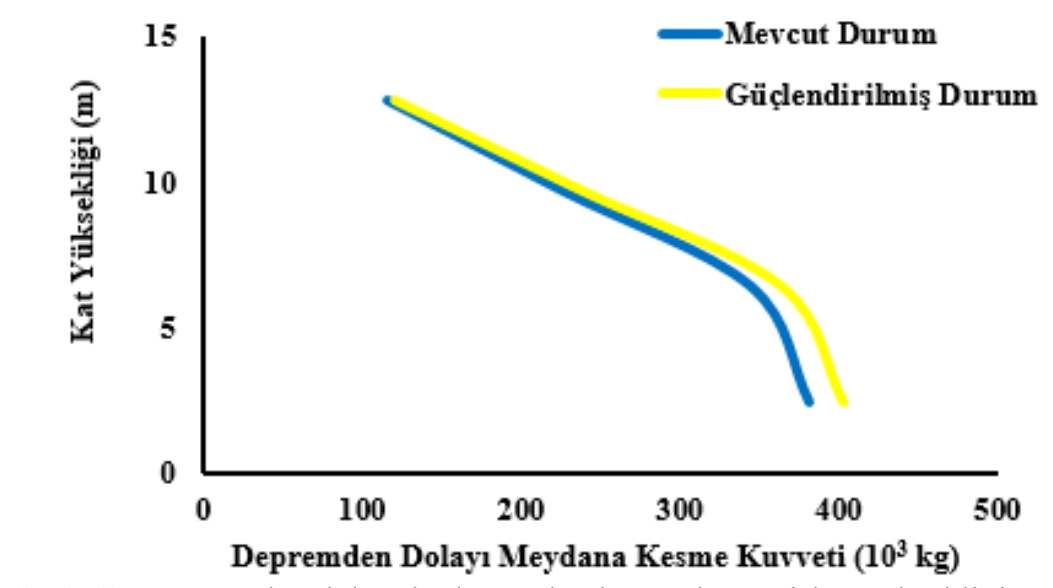

Şekil 12. Depremden dolayı katlara gelen kesme kuvveti-kat yüksekliği grafiği

\section{Sonuç ve Öneriler}

Bu çalışmada, tarihi yığma yapıların güvenliği ve servis ömürleri için mantolama-güçlendirme işleminin ne kadar önemli olduğunun anlaşılması ve gösterilmesi amaçlanmıştır. Bu amaçla Rombaki tarihi yığma yapısı bu çalışmada 3 boyutlu modelleme için seçilmiştir. Bina modellendikten sonra binanın mevcut durumu analiz edilmiştir. Daha sonra binanın belirli kısımlarına mantolama yaparak binanın performansının hemen kullanım olması sağlanmıştır (2018 Deprem Yönetmeliği). Yapılan analiz sonuçları göz önüne alınarak aşağıda belirtilen önerilerin dikkate alınması faydalı olacaktır.

- Tarihi yığma yapıların güçlendirme mantoları ile sağlamlaştırılması bu yapıların uzun ömürlü olmaları için çok büyük önem arz ektedir. Ancak bu mantolama işlemi sırasında manto kalınlıklarının ve kullanılan mantonun yerinin binanın tarihi dokusuna zarar vermemesine çok dikkat edilmelidir. Aksi takdirde ülke turizmi için büyük öneme sahip olan bu yapılar çok büyük hasarlar alabilmektedir.

- Tarihi yapıların güçlendirilmesi sırasında mantoların rastgele değil 3 boyutlu modelleme sonucunda hasarlı bölgeler göz önünde bulundurularak yapılmasına özen gösterilmelidir.

- Binanın mevcut durumu ile mantolama sonrası durumu karşılaştırıldığında devrilmeye karşı koyan momentlerin tüm katlar için güçlendirme sonrasında daha fazla olduğu açıkça gözlemlenmiştir. $\mathrm{Bu}$ sonuç, mantolama işleminin tarihi yapıların tarihi dokularına zarar vermeden yapıldığında ne kadar önemli olduğunu göstermektedir. Ayrıca devrilmeye karşı koyan moment diğer katlara oranla en fazla zemin kattaki duvarlarda meydana gelmiştir.

- Depremden dolayı katlara gelen kesme kuvveti mantolama işleminden sonra her kat için -X, $+\mathrm{X},-\mathrm{Y},+\mathrm{Y}$ yönlerinde artış gösterdiği gözlemlenmiştir. Bu sonuç, mantolama işleminden sonra depremden sonra yığma yapılara daha fazla kesme kuvveti geldiğinin bir kanıtıdır.

- Mantolama ve güçlendirme işlemleri yeni 2018 Türk deprem yönetmeliğine göre yapılması gerekmektedir. Bu çalışmada, bu yönetmeliğe uyularak mantolama işlemleri yapılmıştır ve bundan sonra tarihi yapılara güçlendirme yapılırken eski deprem yönetmeliğine uyulmaması gerektiği ve bu yeni yönetmeliğe uyulması gerektiği önerilmektedir.

\section{Yazarların Katkısı}

Çalışmada tüm yazarlar eşit oranda katkı sunmuştur.

\section{Çıkar Çatışması Beyanı}

Yazarlar arasında herhangi bir çıkar çatışması bulunmamaktadır.

\section{Araştırma ve Yayın Etiği Beyanı}

Yapılan çalışmada, araştırma ve yayın etiğine uyulmuştur. 


\section{Kaynaklar}

[1] Örmecioğlu H.T. 2010. Tarihi Yapıların Yapısal Güçlendirilmesinde Ana İlkeler ve Yaklaşımlar. Politeknik Dergisi, 13 (3): 233-237.

[2] Kasapgil M.E. 2007. Eski Eserlerde Yığma Duvarların, Kubbelerin, Tonozların ve Temellerin Enjeksiyon Reçineleri ve Ankraj Sistemleriyle Güçlendirilmesi. Tarihi Eserlerin Güçlendirilmesi ve Geleceğe Güvenle Devredilmesi Sempozyumu, 27-29 Eylül 2007, 215-218.

[3] Kasapgil M.E. 2007. Adana Ulucami Minaresi Güçlendirme Çalışması. Tarihi Eserlerin Güçlendirilmesi ve Geleceğe Güvenle Devredilmesi Sempozyumu, 27-29 Eylül 2007, 219-224.

[4] Sesigür H., Çelik O.C. 2007. Ahi Çelebi Camisinin Onarımı ve Güçlendirilmesi. Tarihi Eserlerin Güçlendirilmesi ve Geleceğe Güvenle Devredilmesi Sempozyumu, 27-29 Eylül 2007, 231-238.

[5] Arığlur E., Anadol K., Arıoğlu A.Ü. 2007. Uluslararası Deprem Mühendisliği Açısından Önemli Bir Olgu ve Kayıp: Güçlendirilmiş Adapazarı Vilayet Binası. Tarihi Eserlerin Güçlendirilmesi ve Geleceğe Güvenle Devredilmesi Sempozyumu, 27-29 Eylül 2007, 241-254.

[6] Aydın A.P., Kul F.N., Dönmez C., Erberik A. 2015. Urla Eski Tekel Binası (Arditi Köşkü): Yangın Öncesi Durum ve Yapısal İyileştirme-Güçlendirme Kararları. 5. Tarihi Eserlerin Güçlendirilmesi ve Geleceğe Güvenle Devredilmesi Sempozyumu, 1-3 Ekim 2015, 13-28.

[7] Sert H., Partal E.M. 2015. Tarihi Köprülerin Restorasyonları Kapsamında Yürütülen Yapısal Analiz Çalışmaları ve Sonuçları. 5. Tarihi Eserlerin Güçlendirilmesi ve Geleceğe Güvenle Devredilmesi Sempozyumu, 1-3 Ekim 2015, 83-97.

[8] Türker T., Bayraktar A., Kocaman İ., Çoruhlu B. 2015. Ölçekli Yığma Taş Kemer Köprü Modelinin Dinamik Davranışının Deneysel ve Analitik Olarak İncelenmesi. 5. Tarihi Eserlerin Güçlendirilmesi ve Geleceğe Güvenle Devredilmesi Sempozyumu, 1-3 Ekim 2015, 113-126.

[9] Sert H., Y1lmaz S. 2015. Tarihi Malabadi (Batman Su) Köprüsü'nde Yürütülen RestorasyonKonservasyon Çalışmaları. 5. Tarihi Eserlerin Güçlendirilmesi ve Geleceğe Güvenle Devredilmesi Sempozyumu, 1-3 Ekim 2015, 143-153.

[10] Onat O., Sayın E. 2015. Tarihi Tağar Köprüsünün Doğrusal Olmayan Sismik Analizi. 5. Tarihi Eserlerin Güçlendirilmesi ve Geleceğe Güvenle Devredilmesi Sempozyumu, 1-3 Ekim 2015, 301-311.

[11] Mahrebel H.A. 2006. Tarihi Yapılarda Taşıyıcı Sistem Özellikleri, Hasarlar, Onarım Ve Güçlendirme Teknikleri. Yüksek Lisans Tezi, İstanbul Teknik Üniversitesi, Fen Bilimleri Enstitüsü, İstanbul.

[12] Domaneschi M., Cimellaro G.P., Scutiero G. 2019. A simplified method to assess generation of seismic debris for masonry structures. Engineering Structures, 186: 306-320.

[13] Zhang S., Beyer K. 2019. Numerical investigation of the role of masonry typology on shear strength. Engineering Structures, 192: 86-102.

[14] Zhang S., Beyer K. 2018. Seismic vulnerability of historic masonry buildings: a case study in the center of Lucca. Procedia Structural Integrity, 11: 169-176.

[15] Masoomi H., van de Lindt J.W. 2016. Tornado fragility and risk assessment of an archetype masonry school building, Engineering Structures, 128: 26-43.

[16] Araújo A.S., Oliveira D.V., Lourenço P.B. 2014. Numerical study on the performance of improved masonry-to-timber connections in traditional masonry Buildings. Engineering Structures, 80: 501-513.

[17] Işık E., Öztürk G., Velioğlu E. 2016. Bitlis İlinde Bulunan Tarihi Bir Yığma Yapının Deprem Güvenliğinin Belirlenmesi. BEÜ Fen Bilimleri Dergisi, 5 (1): 59-64.

[18] Karaşin İ.B., Eren B., Işık E. 2016. Mevcut bir yığma yapının farklı hızlı değerlendirme yöntemleri ile değerlendirilmesi. Dicle Üniversitesi Fen Bilimleri Enstitüsü Dergisi, 5 (2): 70-76.

[19] Işık E., Antep B. 2018. Ahlat İlçesinde Yer Alan Tarihi Yığma Minarenin Yapısal Analizi. BEÜ Fen Bilimleri Dergisi, 7 (1): 46-56.

[20] Işık E., Aydın M.C., Ülker M. 2016. Performance Evaluation of a Historical Tomb and Seismicity of the Region. Bitlis Eren Univ J Sci \&Technol, 6 (2): 59-65. 